\title{
Kant's Practical Postulates and the Development of German Idealism
}

\begin{abstract}
Kant's moral theology was a subject of intense debate in the early reception of Kant's philosophy. At the same time, Kant's notion of practical postulation held considerable interest for Fichte, Schelling, and Hegel. What I seek to show is the systematic connection of these two facts: examination of the ways in which Kant's postulates of pure practical reason exposed the Kantian system to criticism sheds light, I argue, on some of the fundamental moves made by the German Idealists in their transformation of Kant's philosophy.
\end{abstract}

It is a familiar idea that, in order to understand German Idealism, we need to go back to Kant and see how there might be found in him the grounds and means for going beyond him, and there are no shortage of points in Kant from which the German Idealist development may be projected: Kant's theories of the self and of human freedom, the subjectivism of transcendental idealism and its questionable solution to the problem of skepticism, and the problematic bifurcation of freedom and nature, to name but a few. What I seek to do here is add another element to the narrative, which it seems to me has not received due emphasis, namely the central role played by the practical postulates of Kant's moral theology.

The moral theology and Kant's conception of practical postulation held considerable interest for Fichte, Schelling, and Hegel. Writings which stand out as testifying to the German Idealists' concern with this part of Kant's system, and displaying a wide range of attitudes towards it, include the following, in chronological order: Fichte's Kritik Aller Offenbarung (1792); Schelling's writings in his earliest Fichtean period, in particular the Philosophische Briefe über Dogmatismus und Kritizismus (1795) and Abhandlungen zur Erläuterung des Idealismus der Wissenschaftslehre (1797-98); Hegel's Jugendschriften (from 1793 to 1799); Fichte's divine governance essay (1798) and Die Bestimmung des Menschen (1800); and Hegel's Glauben und Wissen (1802), along with the discussion of the moral world-view in the Phenomenology (1807). And for good measure, there is the striking assertion in the Oldest System-Programme fragment (1796/ 97[?]):

Since the whole of metaphysics will in the future fall under moral [theory] - of which Kant, with his two practical postulates, has given an example, but not exhausted anything - this 
ethics will be nothing other than a complete system of all ideas [Ideen], or, what comes to the same, of all practical postulates. (Unkown 1995, 199)

I am not of course going to attempt to go over all of this territory, or even very much of it. In particular, I will say little about Hegel. What I want to explore, with reference to Fichte and Schelling, is the idea of a logical continuity from Kant's conception of practical postulation to the formation of post-Kantian idealism. The notion I wish to make plausible is that the references to Kant's practical postulates scattered across German Idealist texts reflect a systematic connection, can be described in a unified way, and which casts light on both the reasons why a transition was made from Kantianism to the post-Kantian idealisms, and also the means by which it was effected. ${ }^{1}$

This is therefore something more than a simple claim of historical influence, but it is obviously not to say that the moral theology and practical postulates hold a golden key to the German Idealist development, and I am not going to enter any claim about their relative weight in comparison with other motivating sources internal to Kant's system. In fact, what I hope will come clear is that that would be the wrong way of viewing the role played by the postulates, which has to do not so much with substantive first-order issues - the self, freedom, skepticism, etc. - but rather, at a metaphilosophical level, with how those issues are taken up.

That there should have been much engagement with Kant's moral theology on the part of the German Idealists, and that any of it should be positive, as it is in the System-Programme, is in a way somewhat surprising. The moral theology is the most philosophically conservative part of Kant's system, the point where Critical philosophy supplies the "practico-dogmatic metaphysics" which rejoins and redeems the Leibnizian-Wolffian philosophy, and the theism for which it provides does not form part of the motivating agenda of the Wissenschaftslehre, and is explicitly rejected by Schelling in his early days. ${ }^{2}$ Indeed, parting company with theism - and rejecting the idea that reconstruction of religious orthodoxy is any criterion of philosophical success - seems to be one of the features which distinguishes the German Idealist development from the early Kant reception of Reinhold et al., and which in the eyes of many helps to give it a congenially late modern character.

1 Writers who single out and ascribe importance to the connection include (Düsing 1999), (Franks 2005, Ch. 6), (di Giovanni 2005), (Jaeschke 1990, Ch. 1), and (Timm 1974).

2 Most explicitly in Schelling's letter to Hegel, 4 February 1795; in (Frank/ Kurz 1975, pp. 125 128). 
Furthermore, it is not easy to see how the standing of Kant's moral theology in the early to mid 1790s - on the one hand subject to fierce and effective philosophical criticism, and on the other endorsed and appropriated by religious conservatives $^{3}$ - could have led a progressive Kantian to consider it a promising part of the Critical system to fix their attention on. But what I will also try to show is that the difficulties of the moral theology are part of the systematic connection; the problems of Kant's moral theology help to define the philosophical solutions of German Idealism. ${ }^{4}$

My discussion falls into four parts. In the first I look at the use made of the concept of a postulate in Fichte and Schelling, and in the second at the problems of Kant's moral theology. The third part spells out their systematic connection. The fourth part reviews contrasting treatments of the same Kantian material in Beck, Fries, and Novalis.

\section{The postulates in German Idealism}

\subsection{Fichte}

Fichte's use of the concept of a postulate or postulation runs from the beginning to the end of his philosophical development. After beginning to rethink Kant's moral theology in the Kritik aller Offenbarung, where Fichte claims that transcendental idealism itself - the doctrine that things are appearances not things in themselves - is "just as much a postulate of practical reason as a theorem of theoretical reason" (Fichte 1978, p. 25 [FW: V, 36]), ${ }^{5}$ the concept recurs in early writ-

3 Kant's moral theology had been annexed to the Lutheran orthodoxy by senior figures at the Tübingen Stift. The central figure in the so-called 'Älteren Tübinger Schule' of biblically grounded rational supernaturalism, Christian Storr, published in 1794 his Bemerkungen über Kants philosophische Religionslehre, which took up Kant's religion book and Fichte's Kritik aller Offenbarung, seeking to recruit Kantian philosophy to the cause of Church doctrine by showing that there is no real conflict between it and Scripture, and even that there are positive Kantian grounds for ecclesiastical doctrines (such as the Trinity) which Kant himself had not underwritten. Schelling and Hegel had intensive exposure to Storr's views from the day of their arrival.

4 What I wish to show, then, is that the significance of the postulates exceeds, and is not just a matter of their close association with, the unificatory project of the third Critique and the doctrine of the primacy of the practical of the second: they are concerned with what results from Kant's attempt to unify Freedom and Nature on a practical basis.

5 In addition Fichte classifies as a postulate the bare possibility that the moral law should be related to the world of sense (Fichte 1978, p. 27 [FW: V, 38]). This assertion of a fundamental unity of Freedom and Nature is a much broader version of Kant's notion of practical reason's 
ings from the period when Fichte was preparing the Wissenschaftslehre, the "Eigene Meditationen" and "Praktische Philosophie", where the primary proposition that I am aware of my Ich is referred to as a postulate or "Heischesatz" ((Fichte 1971a, [FW/GA: II, III, 26-28, 49-50, 100]), and (Fichte 1971b, [FW/ GA: II, III, 265])), ${ }^{6}$ said to express the very intuition which it demands; ${ }^{7}$ and as late as 1812 Fichte talks of the "Postulat" of the "appearance of the absolute as such", the postulate of its projection of a "Bild" and representative of its own being. 8

Standardly Fichte uses the concept of a postulate in foundational contexts which have to do with the unification of the theoretical and the practical, and hence with the basis of ontological talk, and at points where none of the other and more familiar concepts in Fichte's lexicon could express adequately the distinctive status of the claim that he wants to make. ${ }^{9}$ Three texts in particular reveal this.

requirement of the necessary unity of happiness and moral worth: Fichte treats that narrower notion, of the congruence of the fortunes of moral being with their behaviour, as deducible from the broader. Fichte's conception of the necessity of a fundamental unification of realms goes back to his early reflections on Kant's third Critique, his Versuch eines erklärenden Auszug aus Kants Kritik der Urteilskraft, where he says that the 'Vereinigungspunct' of Freedom and Nature must be 'weder theoretisch noch practisch' (Fichte 1962, [FW/GA: II, I, 329-330]). Fichte is also much less insistent than Kant on the need for the theological postulates to enable effective moral motivation (consequently Fichte denies religion even subjective universal validity: (Fichte 1978, p. 42 [FW: V, 56-57]). The overall tendency of the Kritik aller Offenbarung is thus to absorb Kant's antinomy of practical reason into the much more general and fundamental problem, acknowledged by Kant in the Introduction to the third Critique, of the 'Kluft' between Freedom and Nature (Kant 2000, [AA 5:175-176]). It is to be noted that, at this point, Fichte is not aiming to modify the concept of a practical postulate, Kant's definition of which he simply restates: a postulate is a theorem immediately connected with reason's requirement of practical law, which is 'not commanded by the law', yet 'must necessarily be assumed if reason is to be legislative', and which we call a 'belief' (Fichte 1978, p. 31 [FW: V, 41]).

6 Two interconnected reasons are given: that intuition is required, and that each can become aware only of his own Ich. One formulation of the primary proposition entertained by Fichte is imperatival: 'Schaue Dein Ich an.' The second proposition, concerning the necessity of consciousness of Nicht-Ich, is also called a postulate. In (Fichte 1971b, [FW/GA: II, III, 190-191]), Fichte talks of an Erfahrung of our original striving as postulirt - 'das Postuliren der Erfahrung ... es soll empfunden werden können' - and of our having come to 'all possible practical postulates'.

7 'Die Anschauung, welche in diesem Satze gefordert wird, ist durch ihn selbst ausgedrückt', (Fichte 1971a, [FW/GA: II, III, 50]).

8 '... aus dem Postulate der Erscheinung des Absoluten als solchen', (Fichte 1971, [FW: X, 352]). 9 Fichte's usage is not entirely consistent; in some contexts he uses the term as a mere synonym for positing (Fichte 1982, pp. 196 and 260 [FW: I, 218 and 296]). 
(1) In the 1794 Grundlage Fichte refers to a postulate not formulated by Kant but which, he supposes, underlies Kant's moral theory (Fichte 1982, pp. 230n2 and 232 [FW: I, 260n and 263]). ${ }^{10}$ This is the "absolute postulate of conformity with the pure self", the demand "that everything should conform to the self". Fichte suggests that the categorical imperative is, or may be considered "as", just this postulate. Whatever the justice of this construal of Kant, the important point is what seems to be Fichte's further claim, that what the imperative requires, for its intelligibility, is a theoretical grounding. It requires the notion that "the self is itself absolute": "Only because and insofar as the self is itself absolute [Nur weil, und inwiefern das Ich selbst absolut ist], does it have the right to postulate absolutely.” (Fichte 1982, p. 230n2 [FW: I, 260n]). Fichte says that Kant could never "have arrived at the categorical imperative' without 'presupposing an absolute being of the self [absoluten Seyns des Ich]". ${ }^{11}$

This immediately raises the question: Is Fichte thinking of the absolute self, with its absolute being, as a metaphysical ground? Or is it a mere ideational correlate, the theoretical echo as it were, of a practical norm? The first is suggested by Fichte's claim that the absolute being of the self is the "ground of the authority [Grund der Befugniss]" of the absolute postulate, ${ }^{12}$ and the second by the fact that his broader intention is, we know, to in some way ground theoretical on practical reason.

The passages later in the Grundlage where Fichte tells us what it means for the self to have absolute being favour the second interpretation, but fail to fully

10 The theism of Kant's moral theology, more or less conserved in the Kritik aller Offenbarung, has by this point disappeared. Fichte's theological views are not on open display in the Grundlage but can be gleaned from the contemporaneous 'Praktische Philosophie' (Fichte 1971b, [FW/ GA: II, III, 238]): belief in the existence of God derives from the subject's original striving, which 'geht darauf hinaus, Gott zu werden'; in the Trieb to discover God shines the law, 'werde selbst Gott'. Fichte describes this result of his investigation as a 'guter Fund'. This is not in fact the position that Fichte defends publically in his later essay on divine governance (Fichte 1994), but it is very close to the recognizably Fichtean analysis that Friedrich Karl Forberg articulated (Forberg 1912), precipitating the Atheismusstreit.

11 In one place Fichte contrasts the Wissenschaftslehre, which distinguishes 'absolute being' from 'real existence' and takes the former as a ground for the latter, with Stoicism, which does not distinguish them (Fichte 1982, p. 245 note 4 [FW: I, 278n]).

12 The point is this: Fichte has claimed that the moral imperative of the moral law presupposes an assertoric, non-imperatival ground, so it cannot be Fichte's view that we grasp what it is for the self to be absolute merely by assenting to certain norms; the absoluteness of the self is what is supposed to ground (rationalize our assent to) those norms. This reading is suggested, moreover, by remarks in 'Praktische Philosophie' (Fichte 1971b, [FW/GA: II, III, 238]) to the effect that the unconditioned is not realized in theoretical reason (for which it is merely regulative), but that pure reason, in the pure Ich, realizes absolute unity (though only for the pure Ich). 
clarify the situation (Fichte 1982, pp. 238-239, 244-245 [FW: I, 270-271, 277278]). Fichte says that the self is infinite, "but merely in respect to its striving": it merely strives to be infinite (Fichte 1982, p. 238 [FW: I, 270]). Again, he says that the self demands that it encompass all reality, that this demand rests on the idea of the absolutely posited infinite self, and that the meaning of the principle, the self posits itself absolutely, becomes clear when we appreciate that we are speaking of "an idea of the self which must necessarily underlie its infinite practical demand" (Fichte 1982, p. 244 [FW: I, 277], italics added). But this just leaves us with the puzzle of why Fichte in the earlier passage attributed absolute being to the self, and of how an idea which does not (yet) possess an object, can lend authority to a practical demand. ${ }^{13}$

I will come back to this, but for the moment the point is just that Fichte draws a direct connection of foundational issues in the Wissenschaftslehre with Kant's concept of practical postulation, while seeming to depart from the pattern of Kantian practical postulation. Rather he seems to have in mind and see the need for some development of Kant's notion - Fichte seems to envisage some sort of reflexive structure in which "ought" and "is" double up and validate one another.

(2) This supposition is borne out in the "new presentation" of the Wissenschaftslehre (nova methodo) (Fichte 1992). Here Fichte tells us that the Wissenschaftslehre begins, as all philosophy must, with a postulate, but it is one "that is grounded in an Act [Thathandlung] and not in a fact", where "Thathandlung” means: "what occurs when I let my I act within itself and observe what happens", namely the construction of a world, "a continually progressing synthesis" (Fichte 1992, pp. 109-110 [FW/GA: IV, III, 344-345]). ${ }^{14}$ We might briefly wonder if Fichte wants us to understand by postulate anything more than is in-

13 The ambiguity concerning ontological commitment, again in connection with the concept of a practical postulate, is present also in Fichte's account of human freedom in his review of Creuzer, where he describes 'manifestation of absolute activity in the determination of the will' as a Postulat of the moral law (Fichte 1971, p. 293 [FW: VIII, 413]), and recommends that the question of whether we should think of this activity which supplies the 'real ground' of empirical acts of will as 'the cause', the Ursache, of the will's being determined, should be answered negatively: the sufficient ground of determinations of the will is not to be identified with 'an actual real ground' (Fichte 1971, p. 294 [FW: VIII, 414]). For a general discussion of the issue of the Wissenschaftslehre's ontological status, see (Gardner 2007).

14 Alternative specifications of the primary postulate are given: 'that this free activity of his I is that principle that cannot be derived from anything else' (Fichte 1992, p. 95 [FW/GA: IV, III, 335]); 'Construct the concept of the I and observe how you accomplish this' (Fichte 1992, p. 119 [FW/ GA: IV, III, 349]). Later the postulate is added that: 'The I appears outside of itself, as it were, and makes itself into an object' (Fichte 1992, p. 138 [FW/GA: IV, II, 44]). 
volved in the basic Euclidean geometrical case, ${ }^{15}$ but all such doubts are removed when he later writes: "Moreover, the scope of Kant's practical postulate is too narrow, for he limits it entirely to belief in God and immortality; but we will see that consciousness in its entirety is included within this postulate." (Fichte 1992, p. 298 [FW/GA: IV, II, 139])

The postulate to which Fichte is referring here is Kant's claim that "I ought to do something; therefore, what I ought to do must be possible" - which is equivalent, Fichte says, to his own claim that the I must effect, within my thinking and my willing, a transition from determinability to determinacy. ${ }^{16}$ So the operative conception of postulate here is not just a postulate in the basic Euclidean sense but explicitly tied to Kant's moral theology. Fichte attributes Kant's not having presented his philosophy as a whole under the rubric of a transition from Ought to Is, i.e. as a set of postulates, to the order in which the Critiques were composed; to have done so would have required Kant to go back and laboriously revise his critique of theoretical reason. In other words, had Kant begun with a treatment of the I "as it is for itself", instead of treating it as an "accident" of "sensible, objective thinking", then he would have arrived at the postulates of the Wissenschaftslehre.

(3) In the 1804 lectures, Fichte attempts to recast the Wissenschaftslehre in terms that will show it to possess the virtues claimed for Schelling's identity system; that is, he wishes to show that his own system is no merely one-sided, merely subjective idealism, but that it grasps as much of the absolute as can be thought possible. Fichte proceeds by playing off different formulations of realism and idealism against one another, in a way that leads to their successive refinement and finally to the insight of non-objectified being, "a being in pure act" which is "self-enclosed oneness with itself" (Fichte 2005, p. 116 [FW: X, 206]). ${ }^{17}$ This concludes the first of his two major tasks.

15 Fichte draws the analogy with geometry, (Fichte 1992, p. 110 [FW/GA: IV, III, 344-345]), no doubt with Beck (whom he has just been discussing) in mind.

16 More exactly, Fichte describes Kant's principle as analytic, and his own as synthetic (Fichte 1992, p. 297 [FW/GA: IV, II, 138-139]).

17 'simple, pure being as absolute, self-enclosed oneness' (Fichte 2005, p. 120 [FW: X, 212]), 'an unconditionally self-enclosed, living oneness' (Fichte 2005, p. 147 [FW: X, 245]) which we do not go toward, for the reason that we ourselves are (in) it; our insight is that 'being itself is an absolute I', or We (Fichte 2005, pp. 117 and 120 [FW: X, 207 and 212]), because it is not just already constructed but self-constructing (Fichte 2005, p. 122 [FW: X, 214-215], which refers back: the being which we had insight into 'constructs itself, and ... is only in this self-construction'). This being is 'entirely of itself, in itself, and through itself', where this 'self' involves no antithesis (of subject and object) because it is 'grasped with the requisite abstraction purely inwardly ... as I am most fervently conscious of grasping it’ (Fichte 2005, p. 116 [FW: X, 205]). 
The second task, which we are set as soon as the first is completed, ${ }^{18}$ is to "deduce from the first part, as necessary and true appearance, everything which up to now we have let go as merely empirical and not intrinsically valid" (Fichte 2005, p. 121 [FW: X, 213]), what Fichte calls "factical existence". ${ }^{19}$ And the difficulty we face here is that of avoiding an irrational gap, hiatum, of the kind that confronts us, Fichte claims, when we consider the relation of consciousness to objects: ${ }^{20}$ the relation of pure being to appearance should not reproduce the "inexplicable and inconceivable" character of that relation.

Fichte's first step towards a solution is to hypothesize a relation of "Sollen", staked on the condition of our own cognition into the essence or ground of being: If the cognition - the "absolute insight" (Fichte 2005, p. 125 [FW: X, 218]) - that we achieved in completing the first task is to be possible, then being should (es soll) construct itself in a way that allows it to make itself known to us. Fichte calls this the ideal self-construction of being (Fichte 2005, p. 123 [FW: X, 215]). He then asks us to reflect on the essence of this Sollen, and says that:

... an inner self-construction is expressed in the 'should': an inner, absolute, pure, qualitative self-making and resting-on-itself ... It is, I say, an 'inner self-construction', completely as such: nothing else supports the hypothetical 'should', except its inner assumption entirely by itself and without any ground [die innere Annahme durchaus von sich selber und ohne allen aüssern Grund] ... 'Inner assumption entirely by itself' I have said: hence a creation from nothing, producing itself as such. A 'resting on itself' I have said, because ... it falls back into nothing without this continuing pursuit of inward, living assumption [innerlich lebendigen Annahme] and creation from nothing. Hence it is the self-creator of its own

18 The transition from the first to the second takes place in Lecture 16. The part of the text which I am concerned with in what follows runs from this point in Lecture 16 to Lecture 21 inclusive.

19 (Fichte 2005, p. 122 [FW: X, 214]): 'being's factical existence in the form of external, objectifying existence'. Fichte specifies the target in different ways: 'if we wanted to come to something more than the one being, for example to the latter's way of appearing ... primordial appearance; and so consciousness' (Fichte 2005, p. 128 [FW: X, 222]); '... if appearance is to arise' (Fichte 2005, p. 146 [FW: X, 245]); 'this entire manifold as it occurs empirically ... to present appearance in general and as such' (Fichte 2005, p. 147 [FW: X, 246]); we seek to explain a priori appearance and its 'principle of the manifold' (Fichte 2005, p. 147 [FW: X, 246]), 'the resolution of the puzzle of the world and of consciousness' (Fichte 2005, p. 151 [FW: X, 251]).

20 Not, note, merely spatially outer objects, but all states of affairs which are taken to obtain, to be matters regarding which there is truth, including our own Denken, in so far as we have Cartesian certain consciousness of thinking: see (Fichte 2005, p. 111 [FW: X, 199-200]). 
being and the self-support of its duration. (Fichte 2005, p. 125 [FW: X, 219], translation modified $)^{21}$

Fichte is referring here to an act which is normatively conceptualized but expresses an ontological ground, an ontologically creative ground.

The crux of Fichte's argument - on which rests the anti-skeptical force of the Wissenschaftslehre, as well as his claim that its idealism is (pace Schelling's criticisms) a higher realism - is his claim that we can convert this hypothetical Sollen into "something categorical and absolute", because it can be regarded, not merely as a condition for our cognition, but also as a principle of pure being itself (Fichte 2005, p. 126 [FW: X, 219]). The antecedent - If we are to have insight, then ... - falls away, Fichte argues, leaving just the consequent: Being must construct itself as factical existence or appearance. ${ }^{22}$ As Fichte puts it, the ideal self-con-

21 Again: the should has 'been illuminated for us as an absolute that holds and sustains itself out of itself and through itself as such, on the condition that it exists', whereby 'we have a categorical insight into the unchangeable, unalterable nature of the "should", an insight in which we can completely abstract from [its] outward existence' (Fichte 2005, pp. 131-132 [FW: X, 227]); the should is 'self-producing and self-sustaining' (Fichte 2005, p. 134 [FW: X, 230]); 'the "should" is the basic principle for everything' (Fichte 2005, p. 135 [FW: X, 231]).

22 Explicating this move occupies Fichte throughout Lectures 17-21. Fichte's argument for the conversion of the conditional necessity (if there are to be appearances of which we have cognition, then being must ...) into an unconditional necessity (being must ...) is not easy to make out, but its nerve is undoubtedly the conception of the former as an instance of Sollen, the importance of which for Fichte cannot be overstated: he refers to it as what differentiates his system from all those which have gone before (Fichte 2005, pp. 148-149 [FW: X, 248]). The task is to 'eliminate' its 'hypothetical status', putting us in possession of the Sollen as a 'self-supporting principle' (Fichte 2005, p. 130 [FW: X, 225]). Fichte says that 'the most secure means is to look it straight in the eye', whereby it loses itself or evaporates in insight into pure being (Fichte 2005, p. 130 [FW: X, 225]). In one place, Fichte describes the search for the ground we are seeking as itself displaying the reality of what we seek - 'in order to state the true result of your desire ... just to arrive at your demand', there must be an 'original seeing' (Fichte 2005, p. 135 [FW: $\mathrm{X}, 232]$ ). The idea seems to be that the conversion is achieved by an alteration of, or abstraction from, form, which leaves just the pure awareness of content (Fichte 2005, p. 144 [FW: X, 242243]): the imperatival normative form of the Sollen falls away, leaving just insight; we 'let go of the proposition's form', viz., of presupposition (Fichte 2005, p. 149 [FW: X, 249]). This is supported by the places in which Fichte claims that our insight into pure being takes us to a point from which we can grasp its differentiation into contrasting forms (real and ideal) as merely downstream features, which change nothing regarding its essential content and identity; allowing is and ought to be regarded as, to put it empirically, different aspects of one and the same thing.

Another strand in the text concerns our own reflexive appreciation of our presence in our reflections as knowers: Fichte tells us to remember that the condition in the antecedent (our having cognition) is actually satisfied, not in the sense of any assumed determinate cognition - 
struction of being encompasses also its real self-construction. ${ }^{23}$ And once the Sollen has been grasped as categorical, not merely hypothetical, Fichte refers to it as a postulate: he talks of the "postulate of the absolute necessity in the pure, positive in-itself" (Fichte 2005, p. 142 [FW: X, 240]), "the postulate that inner being ... must construct itself” (Fichte 2005, p. 147 [FW: X, 246]), "the absolute postulation of genesis", "the 'should [Soll]' is a postulation ... and a postulation is a genesis” (Fichte 2005, p. 155 [FW: X, 256]).

\subsection{Schelling}

Schelling's early writings take up Kant's concept of practical postulation in close association with Fichte, but with several differences. For one thing, Schelling tells us explicitly that that is what is he doing - self-consciously appropriating and revising Kant's conception. There are however also substantive points of contrast with Fichte, of which the first two are these. First, whereas for Fichte,

Fichte's is not a regressive argument in that sense - but in the sense that we are candidates for possessing knowledge, beings for which the minimal and indeterminate possibility of knowledge is assured by the very fact that we can ask what, whether, and how, we can know anything; this allows us to grasp that we 'know ourselves in' the presupposition, and are 'knowing' (Fichte 2005, pp. 151, 153 [FW: X, 252, 253]).

Also important is Fichte's idea that we can and must in our reflection shake off the thought that the Sollen has validity merely relative to us, meaning that being's obligation (so to speak) to construct itself for our sake becomes being's obligation to construct itself for its own sake. The sort of normativity that Fichte has in mind by Sollen must be something like what we grasp in practical consciousness (a normative demand that is fulfilled by a doing), and not the thinner normativity of theoretical reasoning. It cannot be the latter alone, because in that case Fichte's references to doing as opposed to saying would make no sense, and no progress would therefore be made with the anti-skeptical task of validating the presuppositions of theoretical reason: Fichte argues that the enactment [Thun] in the should is revealed to be categorical, even though its saying is hypothetical (Fichte 2005, p. 142 [FW: X, 239]).

As I understand it, when Fichte describes the Sollen as insight into 'genesis' (absolute genesis; genesis of being, and being as genesis), we do not just grasp that something's being the case is a condition of the fulfilment of a mere demand of ours, but that the demand inheres in being itself: we grasp being as having-to-be, as subject to its own self-addressed imperative, so to speak; at the very least we can abstract from the distinction of our own reflection and reason itself (Fichte 2005, p. 152 [FW: X, 252]). This insight is reformulated (from Lecture 19 onwards) in terms of the identity of light (or pure reason) and being (Fichte 2005, p. 144 [FW: X, 243]), where light is characterized in terms of a 'von' (genetic grounding).

23 'The distinction between being's real and ideal self-construction that we made earlier ... is now completely annulled' (Fichte 2005, p. 138 [FW: X, 235]). 
at least prior to 1804, the attraction of the practical postulates begins and ends with their unification of Freedom and Nature, for Schelling it lies not only in their doing this but also, and more importantly, in their thereby taking us to the highest concept or Ideal of Pure Reason. Second, and connectedly, Schelling disposes of any equivocation concerning ontological commitment.

In the Appendix to his 1797-98 Abhandlungen zur Erläuterung des Idealismus der Wissenschaftslehre, Schelling spells out the reasons why "the first principle of philosophy must be simultaneously theoretical and practical, i.e., a postulate" (Schelling 1994, p. 134 [SW: 1, 446]), ${ }^{24}$ "neither theoretical nor practical alone [but] both at once [beides zugleich]" (Schelling 1994, p. 135 [SW: I, 448]). The principle of philosophy cannot be theoretical, Schelling asserts, without surrendering $a b$ initio to dogmatism, nor however can it be practical, since practical propositions are mere imperatives. But in the concept of a postulate we find the theoretical and practical united, in so far as it concerns a "primordial construction" in inner sense, which is theoretical in form but which borrows its compelling force ("zwingende Kraft") from the practical sphere (Schelling 1994, pp. 134-135 [SW: I, 447-448]).

This conception is preserved intact in Schelling's 1800 System of Transcendental Idealism (Schelling 1978, p. 33 [SW: III, 376]):

There is no possibility of our principle forming the basis of both theoretical and practical philosophy if it be not itself at once theoretical and practical. Now since a theoretical principle is a theorem [Lehrsatz], while a practical one is a command, there must lie something in the middle between the two - and this is the postulate which borders on practical philosophy, since it is simply a demand, and on theoretical, since its demand is for a purely theoretical construction. Where the postulate gets its coercive power from, is at once explained by the fact that it is used for practical demands. Intellectual intuition is something that one can demand and expect; anyone who lacks the capacity for such an intuition ought at least to possess it.

The reasons Schelling gives here are therefore of a metaphilosophical kind, and prescind from the consideration that we have in fact located, thanks to Fichte, the particular and uniquely appropriate content for the postulate which the system of philosophy requires. The Fichtean content of the postulate which in fact

24 I focus on this text because it brings to a conclusion the early series - Über die Möglichkeit einer Form der Philosophie überhaupt (Schelling 1980a), Vom Ich als Princip der Philosophie (Schelling 1980), and Philosophische Briefe (Schelling 1980b) - and summates Schelling's views at the end of this first crucial phase of his development, with close reference to Fichte. Schelling's conception of absolute cognition dates from Vom Ich (Schelling 1980), but it is not until the 'Antikritik' that Schelling refers to it as a postulate (Schelling 1982, [SW: 242-244]). 
provides the first principle of philosophy is: "what is undemonstrable and primordially intuitable [Undemonstrierbaren, ursprünglich Anzuschauenden]” (Schelling 1994, p. 133 [SW: I, 444]), which Schelling says is equivalent to the intellectual intuition which reveals to us the origin of self-consciousness (Schelling 1994, pp. 102, 116, 135 [SW: I, 401, 420, 448]).

These characterizations stand in rough agreement with Fichte, as his position stood in the Jena Wissenschaftslehre. ${ }^{25}$ But Schelling's further insight is that there is an alternative to Fichte's strategy of focussing on the Sollen in order to reach the point of identity of the theoretical and practical. On Schelling's alternative, we can lay direct claim to intellectual acquaintance with that which resolves itself immediately for reflection into distinct, theoretical and practical factors, but which in itself is neither, and so can be both. ${ }^{26}$ The absolute postulate discloses the "original identity of the theoretical and the practical in us", and it represents for practical reason the 'absolute state' to be achieved, but it can do so only because our intuition attains, as Schelling puts it in Plato's language, "an intuition of its archetype in the intellectual world" (Schelling 1994, p. 111-112 [SW: I, 413-415]). ${ }^{27}$ Fichte's ought is retained but demoted: for Schelling it is not that as which we grasp being-in-itself, as Fichte has it in 1804 (Fichte 2005), a ratio cognoscendi and ratio essendi, but merely the basis on which we are entitled to postulate the universal validity of our intellectual self-intuition (Schelling argues: since all are capable of heeding the moral law, all possess the capacity for such intuition) (Schelling 1994, pp. 112, 113, 116, 134 [SW: I, 414-415, 416, 420, and 446]).

Schelling thereby removes, as I said, the ambiguity regarding the ontological significance of the absolute postulate. And he takes care to explain how this is

25 In particular, with how Fichte presents the Wissenschaftslehre in the Second Introduction (Fichte 1994a).

26 Schelling defines a postulate as 'the requisite of a primordial (transcendental) construction', without reference to the primacy of practical reason, (Schelling 1994, p. 137 [SW: I, 451]). At this stage, Schelling takes Fichte to share this concept of a postulate: see (Schelling 1994, p. 137n [SW: I, 451n]).

27 See also (Schelling 1980b, p. 180 [SW: I, 318]). Such a point is not merely the node of coordination of practical and theoretical reason, but lies above both. Schelling does not draw attention to this departure from Fichte, and it is obscured by the fact that so much of what Schelling says - concerning theoretical philosophy as 'presupposing' practical philosophy (Schelling 1994, p. 101 [SW: 399]), and of the necessity of grasping oneself as pure autonomy, freedom, etc. - seems to merely recapitulate Fichte. The derivative character of the practical, for Schelling, is nonetheless reaffirmed at (Schelling 1994, p. 114 [SW: I, 417]) - the absolute postulate 'contains the first reason for the practically universal postulates' - and (Schelling 1994, p. 124 [SW: I, 433]): the primordial Sollen has its ground in knowledge itself. 
possible. Propositions which predicate existence are theoretical, ${ }^{28}$ Schelling says, but there is another mode, he argues, in which existence is grasped in transcendental cognition, to which must correspond a distinct sense of existence "Seyn" as opposed to "Daseyn". 29 "Seyn" is what the neither-theoretical-norpractical absolute postulate is concerned with. Thus what threatens to be, as Schelling notes, a "paradox" - namely that one cannot say of the self qua "principle of all reality" that it "exists", since it "possesses none of the predicates that attach to things" - is resolved by saying that the self is being itself, "es das Sein selbst ist" (Schelling 1978, p. 32 [SW: III, 375-376]). ${ }^{30}$

The further point to be emphasized - which I will come to later - concerns the importance of Kant's moral theology for guiding Schelling to his conception of a postulate, which is not just a distillation from his reading of Fichte.

\section{The problems of Kant's moral theology}

\subsection{First responses to the moral theology}

In order to grasp how exactly Fichte and Schelling's uses of the concept of a practical postulate relate to and emerge from Kant, we need to go back to an earlier point in the historical story and consider the first wave of responses to Kant's moral theology. ${ }^{31}$

To an impartial observer of early Kant reception, Kant's moral theology would have appeared by the early to mid-1790s to have emerged from the intensive discussion which it had provoked as at least highly problematic, and this outcome would moreover have been taken as putting a question-mark over the coherence and integrity of Kant's philosophy as a whole. The reasons why the

28 '... ein Satz, der ein Daseyn aussagt', (Schelling 1994, p. 134 [SW: I, 446-447]). And see (Schelling 1994, p. 136 [SW: I, 449]): 'a proposition predicating an existence [der ein Daseyn aussagt] is diametrically opposed to the very spirit of philosophy'.

29 Schelling's position is made clear in an important footnote on the ontological argument and existence of God in Philosophische Briefe (Schelling 1980b, p. 174n [SW: I, 309n]): we are to distinguish the actual (Wirklichen) and the existing (Daseyenden), from being (dem Seyenden); Descartes and Spinoza spoke of absolutes Seyn, which our 'empirical age' misapprehended in terms of the pure concept of existence (Daseyn).

30 This supplies also Schelling's answer to the question, which we might raise, of how a demand-for-a-construction can avoid falling asunder into two components, (i) the demand, and (ii) its object, the theorem.

31 For a more detailed account, see (Gardner 2011), which this section of the paper summarizes and draws on. 
moral theology held such importance for the fate of the Critical system are both historical and systematic. Reinhold had made strident claims for the moral theology as the solution to the Aufklärung's longstanding difficulty in reconciling reason and religion, claims which matched Kant's own statements on the topic; and the specific difficulties which had been identified in criticism of the moral theology had, as Kant's critics took pains to emphasize, direct implications for one's understanding and evaluation of the transcendental project as such.

One set of objections to Kant's moral theology concerned the claims regarding the relation of morality and happiness which Kant makes in the course of arguing that there exists an antinomy of practical reason, which finds its unique resolution in the theological postulates of personal immortality and the existence of God. These problems are of a relatively low-level sort, and were adequately resolved by Kant's defenders through elucidation of what is meant by positing the highest good as a necessary object of will which is nonetheless not a condition of validity of the moral law. Fichte's Kritik aller Offenbarung provides such elucidation (Fichte 1978, §§ 2-3). The objections which are of much greater interest concern two different matters: first, Kant's account of the relation of theoretical and practical reason involved in practical postulation, and second, the epistemic status and ontological commitment of the theological postulates.

Regarding the first of these, the point was hammered home again and again by Kant's critics - inclusive of Flatt, Feder, Schulze, Wizenmann, though many others could be cited - that Kant's invocation of what he calls the primacy of practical reason to rationalize the sanctioning by theoretical reason of the propositions which practical reason claims as "practical cognitions" of the supersensible, fails to achieve coherence. The objection was formulated in different ways, but the common element is a complaint that Kant's move from a need of practical reason to a holding-true, "Fürwahrhalten", violates the independence and autonomy of theoretical reason.

The most forceful statement of the second difficulty is found in Jacobi's Ueber das Unternehmen des Kriticismus and then again in Von den göttlichen Dingen ((Jacobi 1968, pp. 175-195) and (Jacobi 1968a, pp. 340 -378)). These are relatively late texts - respectively 1801 and 1811 - but I will concentrate on them because they articulate in incisive and amplified terms things that anti-Kantians such as Wizenmann and Schulze had been saying in the 1780s and 90s. 


\subsection{Jacobi}

1. In Ueber das Unternehmen des Kriticismus, Jacobi reapplies to Kant's postulates the same type of criticism that he had applied previously to Kant's claim of empirical realism in the supplement, "On Transcendental Idealism”, to his David Hume (1787) book (Jacobi 1994, pp. 331). According to Jacobi, the difference between the two cases, which are otherwise parallel, concerns merely which faculties are involved, with reason occupying in the case of the practical postulates the place occupied by the understanding in empirical knowledge.

The objection is that Kant's own account of the subjective genesis of the ideas of reason, not merely fails to positively endow them with epistemic authority, but makes it impossible to regard them as having any cognitive significance whatever. It is impossible, Jacobi says, to have an "honest, wholehearted confidence" in reason's ideas of God, freedom and immortality, since we are on Kant's account "clearly instructed by the origin, the constitution and the inner essence of these ideas" that they are only "Fictionen" - they arise in us only because they are necessitated to do so by the conceptual operations of the understanding, as needed in order to provide bounds for its extension, and so can only be taken as deceptive horizons, not as things existing for and in themselves (Jacobi 1968 , pp. $100-103) .^{32}$

Kant's claim that religious belief is rationally necessitated by moral consciousness thus requires, so Jacobi argues, theoretical reason to set aside its commitment to truth, and in any case leaves us only in the peculiar reflective position of knowing that our subjective constitution compels us to endorse certain representations, ones which, Kant's own theory of that constitution instructs, are for us necessarily without objective significance. And since the final end, and ultimate justification, of the entire Critical undertaking, according to Kant himself, was precisely to save the three practically significant ideas of reason, we can conclude from his failure in that broader endeavour, Jacobi claims, that the Critical project as such runs aground. And so - Jacobi tells us, drawing an even broader, more sweeping conclusion - must any attempt to philosophize on the basis of mere concepts in abstraction from divine intuitional input (Jacobi 1968a, p. 192).

32 As Jacobi puts it in (Jacobi 1968a, pp. 376-378): If reason relates only to the understanding, and this only to sensibility, and if cognition ascends only gradually from appearances to ideas, then Kant is right, against Plato: the ideas are then expanded concepts of understanding, without provable objective validity, and if their Kantian deduction is correct, then there is nothing more perverse than to proceed from ideas. 
In the later text, Von den göttlichen Dingen, Jacobi - on the search for ever deeper diagnoses of the pathologies of philosophical reason - offers an extended reconsideration of the moral theology in light of post-Kantian idealism. This text is of particular significance for the case I am trying to make, since here Jacobi expresses the view - at a relatively late point, after German Idealism has developed into a mature state - that the moral theology functioned as a logical trigger for the German Idealist development.

Kant himself, Jacobi declares, is thoroughly innocent of anti-theistic intentions. Yet Kant bears an indirect responsibility for Fichte and Schelling, the twin "daughters" of Critical philosophy, since their philosophies are merely consistent applications of his principle that only what the subject has produced, or constructed, can the subject cognize (Jacobi 1968a, pp. 351-352). ${ }^{33}$ This principle doubles with another: that wissenschaftlicher Beweis is required for all claims to knowledge.

According to Jacobi, the practical postulates represent Kant's endeavour to salvage the ideas of God, freedom and immortality in the face of these principles. The reality of the objects of the ideas of reason was for Kant, Jacobi thinks, wholly axiomatic, a basic conviction, but Kant's commitment to Wissenschaft precluded the epistemology which (given the impossibility of a theoretical proof of God's existence) this conviction entailed, namely Jacobi's own epistemology of immediate revelations of reason, since to affirm such original cognitions would be to affirm truths without the possibility of proof. Kant was thus forced into the compensatory strategy of raising up practical reason, rendering cognition of the objects of reason mediate, in order to preserve at least the appearance of proof (Jacobi 1968a, pp. 351-367). ${ }^{34}$ Had Kant followed to its logical conclusion his principle of the necessity of construction for the conceptual grasping of objects, then he would have arrived at the position of Fichte - a nihilism which dissolves being into productions of thought - and ultimately at the atheistic materialist

33 The Kern of Kant's revolution is that we grasp (begreifen, einsehen) an object only in so far as we have it come into our being in thought, are capable of creating it in our understanding (Jacobi 1968a, p. 351; restated on p. 354). Jacobi may be reading Kant in the light of J. S. Beck and Fichte, but he is of course right that the principle is one which Kant accepts: 'we can only understand and communicate to others what we ourselves can produce' (Kant 1999, p. 482 [AA 11:515]). See also Reflexionen 2394, 'Wir sehen nichts ein, als was wir machen können' ( Kant 2005, p. 42 [AA 16:344]) and 2398, 'Wir begreifen nur, was wir selbst machen können' (Kant 2005, p. 42[AA 16:345]).

34 As Kant lowered reason in theoretical philosophy, he raised it up in the practical part, and so was twice right, and twice wrong; Kant failed to combine his double right into a single, simple and complete one, but rather remained split, ambiguous and equivocal (Jacobi 1968a, pp. $364-$ 367). 
naturalism of Schelling. ${ }^{35}$ Kant avoided this catastrophe only at the cost of equivocation; the correct response to his predicament would have been to abandon his commitment to the necessity of wissenschaftlichen Beweis (Jacobi 1968a, pp. 365-366).

2. Whatever we make of Jacobi's argument, it is hard to deny that the practical postulates from Kant's texts without a clear and determinate ontological status. Strictly there are two issues here: whether or not it is required, for Kant's purposes, that the postulates be ontologically committed; and whether or not in any case Kantianism has the resources to provide for it. Jacobi affirms the first and denies the second, ${ }^{36}$ while anti-realist interpreters of Kant deny both ((Forberg 1912), and in our day, (Neiman 1994, Ch. 4)). But what matters for pres-

35 As Jacobi plots the historical story in Von den göttlichen Dingen (Jacobi 1968a, pp. 372-394): Kant's philosophy was orientated from the outset towards the defence of science in the sense of empirical knowledge, and so he prioritized the understanding over reason. Understanding falls, however, under the shadow of reason: it cannot help wanting to view all things transcendently, and in relation to a single principle. Reason does in fact have, intuitively, transcendent knowledge, but understanding cannot allow this. What it does instead is to substitute for reason's original intuitive knowledge certain ideal constructs that are indeed also products of reason, but which are made up of abstractions derived from the understanding, and which have no content of their own. These abstractions then eclipse the actual knowledge that reason has: because reason is unable to recognize the knowledge that it genuinely has in the abstractions that have been constructed for the sake of the understanding, it ends up treating its original ideas as mere illusions. Fichte followed suit, but reconstructed the whole of nature a priori from logic. The fact that the resulting reconstruction has no content of its own, and needs to derive its content from the material details of nature, led inevitably to its conversion into a form of materialism; Schelling made the necessity of this move explicit. Thus Kantianism reaches the same result as Spinoza. In sum, on Jacobi's account, philosophy arrives at naturalism either directly, along Spinoza's route, or via a circuitous transcendental excursus: transcendental philosophy is bound to resolve itself into naturalism, either because it gives priority to empirical knowledge claims, or because, even when does it not do so, its commitment to pure a priori thought, as against intuition and Gefühl, leaves its constructions without any reality or content, and in order to correct this deficiency, it must surrender itself to nature.

36 The ontological problem is restated by (Adorno 1973, p. 391): 'What Kant alludes to with respect to freedom would apply to God and immortality as well, only more so. For these do not refer to any pure possibility of conduct; their own concepts make them postulates of things in being, no matter of what kind. These entities need a "matter", and in Kant's case they would depend entirely upon that visuality whose possibility he excludes from the transcendent ideas. The pathos of Kantian intelligibility complements the difficulty of ascertaining it in any way ... The concept of the intelligible is not one of a reality, nor is it a concept of something imaginary. It is aporetical, rather.' Adorno shares Jacobi's view of the moral theology as representing a crux of the Enlightenment project: see the extended discussion in (Adorno 1973, pp.361-408). 
ent purposes is that, although of course the practical postulates qualify by Kant's official lights as cognitions, the Kantian conception of a practical cognition does not allow a confident answer to be given to the question whether or not the objective reality of practical cognitions as they figure in the moral theology, involves the same robust degree of reality as theoretical reason is able to secure for empirical objects and to think for things in themselves. And this indeterminacy derives from two sources, corresponding to each of the criticisms levelled against the moral theology: from their being grounded in practical reason, and so doubtfully capable of truth; and from their being products of autonomous self-relating reason, and so doubtfully capable of objective reference.

On Jacobi's account, Kant's postulates thus represent an unhappy compromise between recognition of the unshakeable character of the root convictions of natural consciousness, and commitment to the necessity of proof and consequently to the principle which identifies cognition with construction (and which, per Jacobi, strips them of ontological commitment). One does not need to accept Jacobi's full diagnosis, however, in order to concur with his assessment of Kant as operating with two models which are in tension with one another: first, of practical reason in its pure form as a higher form of cognition, which grasps the supersensible with full ontological import; ${ }^{37}$ and second, of practical reason in the narrow, plain sense of a power directed to producing actions.

The ambiguity that we encounter when we attempt to get the practical postulates into focus - when we try to work out exactly what they commit us to, and what entitlements to knowledge they provide us with - bears a close resemblance, which is certainly not accidental, to the peculiar duck/rabbit effect that Jacobi famously discovered in transcendental idealism: Just as reflection on transcendental idealism from its inside, where empirical reality seems secure, leads us out to a standpoint from which the doctrine appears, on the contrary, ontologically nihilistic, so similarly the standpoint from which the moral proofs appear effective gives way to a standpoint from which they appear to have gained nothing for practical reason.

37 And which even, like Jacobi's Glaube, enjoys a degree of immediacy, in so far as Kant's justifications of the postulates are intended not as deductions but merely for the defence of antecedently formed convictions, spontaneously generated by the moral disposition. 


\section{The systematic connection}

\subsection{Kant's augmented sense of a practical postulate}

Now I want to try to state the systematic connection in the terms that I promised at the outset.

The concept of a postulate as it emerges from Kant's moral theology is an augmented conception, which needs to be distinguished from the generic sense of postulate derived from Aristotle via Euclid. The generic sense - which is the sense that Kant intends in the Postulates of Empirical Thought chapter of the first Critique - is that of a proposition advanced without proof, which we are invited to accept on the basis that nothing speaks against it, and that it promises to lead to results which will recommend the proposition to us. ${ }^{38}$

Kant's augmented conception of a practical postulate incorporates this meaning but has additional, weightier features. It comprises, first, a rationally necessary cognition possessing a distinctive kind of a priori warrant, which is neither that of a Kantian deduction nor that of the Kantian Faktum der Vernunft, but which emerges uniquely from the practical point of view, when (and only when) it reflects on and attempts to coordinate itself with theoretical reason, i.e., when it broaches the standpoint of reason as a whole. Second, it occupies an intermediate, bridging position in relation to theoretical and practical reason, and on account of this dual citizenship, expresses the unity of Freedom and Nature in a manner which sets it apart from other claims in the Critical system. Third, the practical postulates supply ideas of reason with objective reality, furnishing end-points which fulfil, rather than boundaries which restrict, human reason: the theological postulates represent the ground of realization of the highest good, which is the highest idea of practical reason, and they restore to our cognitive stock the Ideal of Pure Reason, the highest idea of speculative reason. They comprise therefore the points in the Critical system where it comes closest to satisfying the Principle of Sufficient Reason. ${ }^{39}$

38 The helpful definition from the Philosophisches Wörterbuch (Schmidt 1974, p. 521), is quoted in (Wallner 1985, p. 297n10): '... a demand, an assumption necessitated by material or logico-intuitive (denkerische) reasons; lacks strict "proof”, but must be posited and made plausible on the basis of facts or for systematic or practical considerations'.

39 Whether and to what extent theoretical reason's concept of God is redeemed is considered by Kant in Section VII of the Dialectic of Pure Practical Reason, (Kant 1996 [AA 5:137-141]). Here Kant affirms that, notwithstanding the impossibility of any increase in our theoretical knowledge of God by way of practical cognition, the Highest Good allows for - because it presupposes an omniscient, all-beneficent, omnipotent being - the determinate thought of a supersensible 
It is in consequence of these features that the practical postulates exhibit the ontological ambiguity which so exercises Jacobi. There are in Kant two vying construals of what it is to be a practical postulate. On the one hand, a practical postulate is grasped in terms of its objective referent, an extra-subjective state of affairs specified by the content of a true judgement - a practical postulate is a claim about how things are. On the other hand, practical postulates have the character of self-directed acts, commitments, or undertakings, in virtue of which no object (over and above the act itself) is in play - a practical postulate is something that an agent does. The intended fusion, but actual collision, of these two construals is manifest when Kant writes that the morally upright man "may well say: I will that there be a God, that my existence in this world be also an existence in a pure world of the understanding ... that my duration be endless" (Kant 1996 [AA 5:143]). The emphasis on the first-person practical standpoint, and the continuity of believing with moral doing, ${ }^{40}$ may seem to shelter Kant from the charge that practical cognition of the supersensible violates Critical strictures on transcendent metaphysical knowledge, but at the same time it implies an identification of postulation with mere intra-subjective manipulation of representations, "belief-states", with an exclusively practical end in view, making "honest, wholehearted confidence" in their truth impossible.

\subsection{The German Idealist development of Kant's conception}

1. The strategy. One reaction to Kant's quandary is to embrace the second horn of Kant's dilemma, and to identify religious faith with sheer moral striving - the strategy formulated (under Fichte's influence) by Friedrich Karl Forberg (Forberg

\footnotetext{
'original being [Urwesens]', a 'first being [ersten Wesens]' and 'author of the world possessed of the highest perfection [Welturhebers von höchster Vollkommenheit]' (Kant 1996 [AA 5:139-140]). If this leaves it uncertain whether all elements of the speculative concept of God including that of ens realissimum are in play and have been underwritten, the Canon of Pure Reason in the first Critique leaves no doubt concerning the objective reality of reason's transcendental Ideal and idea of a necessary being: see (A814-816/B842-844), where Kant says that the moral order leads to the conception of nature as a system of ends originating from an idea, and hence to a 'transcendental theology - a theology which takes the ideal of supreme ontological perfection ... the absolute necessity of one primordial being'. The speculative concept of God is, therefore, validated (subject to all of Kant's usual qualifications) by means of the practical postulates. 40 In this light it may be said that the mere propositions that God exists and that I have an immortal soul (not even, qua their logical connections with objects of pure practical reason) are not postulates, but become so only as and when I do something, viz., postulate their objects in consequence of my moral will.
} 
1912). Another response, which defines the German Idealist reception of Kant's moral theology, is to take the concept of a practical postulate as specifying a target - in other words, to view Kant as having at least identified what needs to be provided. On this account, Kant is to be regarded as exactly right about the postulates to the extent that he supposes claims of such a sort to be necessary for a system of Critical philosophy, but as having failed to show that and how Critical philosophy makes them possible. On this view, the Kantian system has overreached itself in the moral theology, yet has done so with all justification. The concept of a practical postulate would thus represent for progressive post-Kantians a problem to be solved, and which is to be solved by more idealism rather than less. The value of Kant's practical postulates for German Idealism consists accordingly not in their provision of any philosophical doctrine but in their giving a forward-looking definition to the problems of Kantianism - they project the kind of philosophical move required in order for those problems to be resolved.

Such a strategy can be held to to take full account of the criticisms levelled by Kant's critics, while drawing an opposed conclusion. According to Jacobi and others taking the side of Glaube, the hopelessly compromised, ersatz faith offered by Kant's rational religion displays in gross form the futility of the Copernican endeavour to make the subject the ground of all normative claims. At the other extreme, according to Kant's rationalist critics, if the moral theology works, then it can only be because it shows the unavoidable necessity of confidence in the spontaneous products of pure reason; so it leads us back to where we were before the Copernican revolution. ${ }^{41}$ On the German Idealist construal, both of these outcomes can be avoided by redeveloping - by, as Schelling puts it, by an intensification of - the concept of practical postulation. On this account, practical postulates represent what might be called background, or second-level, transcendental conditions, extrapolated from the front-line conditions of possibility of objects, the conditions which figure in the conclusions of transcendental proofs and which constitute the objects which they condition. Practical postulates - or what began as such in the Kantian system - would accordingly comprise conditions of the conditions which directly make objects (theoretical and practical) possible. They would satisfy Critical strictures and retain a claim to being properly transcendental, while having potentially the same reach as the intuitions of reason to which early modern rationalism laid claim: they would comprise, as it were, pure reason rehabilitated, purged of dogmatic contamination. The postulate strategy thus holds out the promise - already intimated in

41 This is the implication of Johann August Eberhard's critique of Kantian philosophy - see (Eberhard 1793 and 1799) - and, in a different way, of Maimon's. 
Kant's claim for a "practico-dogmatic metaphysics" - of recouping, on properly Critical grounds, the sphere of speculative metaphysics.

This claim of logical continuity is supported if we look at Kant's essay, "What Does it Mean to Orientate Oneself in Thinking?" (1786) (Kant 1996b [AA 8:137-139]). Here Kant is trying to walk a straight path between Jacobi’s Glaube and the dogmatic rationalism of Mendelssohn, in the context of the Pantheismusstreit. Kant is required accordingly to show that the Critical philosophy delivers claims regarding the supersensible which are more than notionally distinct from those of dogmatic metaphysics, yet at the same time sufficiently robust to satisfy a theist. To this end Kant refers to, as he puts it, "the right of reason's need [das Recht des Bedürfnisses der Vernunft]", where he means reason in general, as opposed to simply the rights and needs of practical reason. And Kant affirms that the notion of a right based on a need extends to speculative reason as well: ${ }^{42}$ theoretical reason has, Kant says, a legitimate need to take the existence of an original and highest being as the ground of all possibility; reason needs not just to "take the concept" of an unlimited being as the ground of the possibility of all things, but to presuppose "its existence" - "so geht dieses Bedürfniß auch auf die Voraussetzung des Daseins desselben" - and to do so in the mode of holding it true, Fürwahrhalten (Kant 1996b [AA 8:137-138]). ${ }^{43}$ This existential assumption goes beyond, Kant again makes clear, the mere regulative use of reason. ${ }^{44}$ But, Kant adds immediately, the necessity here is merely "subjective" and yields “only a necessary presupposition”, since, he reminds us, a need of reason should not be mistaken for an insight (that being the mistake of the dogmatic rationalist) (Kant 1996b, [AA 8:138n]).

This of course recalls the acute difficulty pinpointed by Jacobi - what can it mean to talk of a necessary presupposition incorporating an ontological claim and possessing truth, which is nonetheless to be regarded as merely subjective? but the key, new point which has come to light here is Kant's recognition that there is need for something, some principle, to lie behind practical reason. Such a principle could not derive its authority from the moral fact of reason, but would instead provide a general principle of warrant for taking reason to have at least potential ontological significance, and the principle of the primacy

42 The passages in question are at (Kant 1996b [AA 8:137-139]).

43 Compare the later discussion in (Kant 2000 [AA 5:402]), where existentially committed belief is not affirmed.

44 The regulative use of theoretical reason - 'Erfahrungsgebrauche unserer Vernunft' - is what Kant has been describing in the preceding paragraph (Kant 1996b [AA 8:136-137]), and it does not require that the right of reason's need be invoked. 
of practical reason would be only a special form of this principle. ${ }^{45}$ In this light, the Fichte-Schelling construal of a highest postulate - to which I will now return - represents the next step that needs to be taken, if the Kantian theory of the rights of reason is to be differentiated from that of the dogmatic rationalist, and to meet Jacobi's objection that it results in mere fictions.

2. Fichte. The augmented sense of practical postulate matches what we saw in the 1804 Wissenschaftslehre, where Fichte affirmed an ultimate point of identity between ontology and normativity, a point where being is grasped as Sollen, which reflection on empirically determined consciousness cannot attest to the reality of, and which therefore cannot be legitimated as a front-line condition of possibility of objects, ${ }^{46}$ but which we are bound to presuppose in its background, as an "upstream" or second-level transcendental condition. The crux of this argument, we saw, lies in the idea of an imperative or practical judgement, a Sollen, that testifies to the reality of (by containing insight into) its own presupposed, theoretically conceived ground: which represents exactly the target defined by Kant's employment in the moral theology of the concept of a practical postulate. ${ }^{47}$ So the Wissenschaftslehre can be held to have done what Kant showed needs to be done for the sake of the moral theology, but failed to actually do, and it has moreover taken up the problems of the moral theology in a generalized form, yielding a general solution to the problem of transcendental proof. As Fichte puts it, in 1804 (Fichte 2005), what we have grasped is that in the case at hand "the bare possibility of this presupposition shows its truth and correctness" (Fichte 2005, pp. 144-145 [FW: X, 243]).48

45 K. F. A. Schelling quotes a lecture fragment from 1803 (Schelling 1988), in which Schelling describes Kant as positing as many reasons as he wrote Critiques: 'one may ask him: Where is the Reason of these Reasons?' (Schelling 1988 [SW: V, viii]).

46 Hence Fichte's emphasis on the problematic, hypothetical, merely presuppositional character of the initial assumption of the Sollen: we 'present [it] only hypothetically as a declaration of pure consciousness ... which we append to being only mediately as an inference' (Fichte 2005, p. 122 [FW: X, 215]).

47 These are defined, in the Jäsche Logic (Kant 1992, [AA 9:86-87]), as 'theoretical' (because they express not 'what ought to be' or 'a possible free action', but rather 'what is') but not 'speculative' (because imperatives can be 'derived from them').

48 We began with 'a mere presupposition, grounding the process of our proof regarding the essence of the absolute, but itself based on nothing', but 'this presupposition proves its correctness simply by its mere possibility and facticity' (Fichte 2005, p. 148 [FW: X, 247]); 'this presupposition is now proven by its facticity and possibility' (Fichte 2005, p. 150 [FW: X, 249]); 'we immediately proved the legitimacy of this presupposition by means of its bare possibility and facticity' (Fichte 2005, p. 154 [FW: X, 254]). 
The 1804 Wissenschaftslehre, I suggest, resolves the ambiguities of the Jena Wissenschaftslehre, which, we can now see, were inherited directly from Kant: Fichte's difficulty in determining whether or not the absolute self has being, or is merely an idea, the projected object of our striving, reproduces the difficulty that Kant's critics identified in determining whether or not the theological postulates can be thought to have objective reality. ${ }^{49}$

3. Schelling. Again, Kant's augmented sense of postulate is continuous with what we find in Schelling in the writings I discussed earlier, and also, even more clearly, in his Philosophische Briefe, written slightly earlier than the Abhandlungen.

This text consists of a critical response to Kant's moral theology and a mediation of Kant and Spinoza. ${ }^{50}$ The two tasks are intimately connected. The mediation of Kant and Spinoza requires above all, on Schelling's account, that we understand the distinction of criticism from dogmatism correctly. And for two reasons he chooses Kant's moral theology as the territory on which to pursue

49 This bears on the issue explored in (Ameriks 2000). In so far as Fichte is construed as pursuing a global strategy of attempting to vindicate epistemological propositions on moral grounds by extending drastically the scope of the principle of the primacy of practical reason, the foundation of which lies in the fact of pure practical reason, it is right to wonder if the Faktum der Vernunft can bear the considerable burden imposed upon it. If it cannot, then it must be concluded that the Wissenschaftslehre reproduces the weaknesses of Kant's moral theology on a larger scale - which was in fact just the complaint of Schelling after his break with Fichte, and of Hegel (as discussed below; see notes 93 and 94). Whether or not this is a correct estimate of Fichte's Jena position, it is clear that in the 1804 Wissenschaftslehre, at least, he does not lean on the principle of the primacy of practical reason as Kant left it: here Fichte aims to solve the problems surrounding the idea that practical reason has authority for theoretical reflection, which he perceives as bound up with general problems attending the transcendental method. Providing some evidence that Fichte had taken the lesson of Kant's critics and was attuned from the very outset to the problems attending practical foundationalism - whether or not the Jena Wissenschaftslehre made a good job of it - see the opening of 'Praktische Philosophie' (Fichte 1971b, [FW/GA: II, III, 181-182]), and (Breazeale 2004, pp. 67-68), suggesting that the Wissenschaftslehre be viewed as a response to the manifest strain of practical postulation, as revealed in Fichte's Kritik aller Offenbarung.

50 As noted earlier, Schelling was exposed to argument concerning the relation of Kantian philosophy to Christian belief at the Tübingen Stift. Henrich 1997 argues for the key role of Immanuel Diez in articulating dissatisfaction, on 'radical Kantian' grounds, with the attempts of Storr and his school at an accommodation of Kant's philosophy with Christian orthodoxy. Schelling's abreaction to Christianized Kantianism is evidenced in his letter to Hegel, 6 January 1795; in (Frank/Kurz 1975, pp. 117-120). The Philosophische Briefe are doubtless targeted above all against the Christian appropriation of Kant, but the scope of Schelling's discussion goes far beyond what is required to challenge claims for the agreement of Kantianism with revealed religion. 
this aim: first because it is the part of Kant's system which has been most conspicuously perverted by religious conservatives, who have misunderstood the distinction of criticism from dogmatism; and second because it is, at the same time, the part of the system in which the spirit of Kantianism comes closest to receiving open expression.

Schelling presents accordingly a detailed critique of the moral theology, the upshot of which, however, is not abandonment of practical postulation, but its reinstatement, in the form of absolute cognition grounded on freedom - which is the real ground of criticism's distinction from dogmatism, and the true respect in which criticism represents a philosophically higher position. Schelling describes the two systems as distinguished by the different spirit of their practical postulates, freedom supplying that of critical postulates (Schelling 1980b, p. 190 [SW: I, 333]). Kant's theism having been disposed of, practical postulation is re-associated with the anti-theism of Spinoza, whose realism it absorbs, counter-balancing Kantian idealism..$^{51}$ And it is also associated by Schelling with tragedy: in an anticipation of the general view of art taken in the 1800 System (Schelling 1978), Schelling describes the state of mind of the tragic protagonist, which tragic art allows us to enter into, as a unification of opposites - of man vs. world, subject vs. "absolute object", freedom vs. necessity, and so on. Tragedy is thus an alternative form which philosophy's absolute postulate, or intellectual intuition, may take (Schelling 1980b, p. 157 [SW: I, 285]).

The argument of Schelling's Philosophische Briefe centres on his repudiation of the, as he sees it, pseudo-Kantian strategy of positing a weakened theoretical reason, the "system of weak reason" (Schelling 1980b, p. 161 [SW: I, 290]). ${ }^{52}$ In addition to generating the paradoxes exposed by Jacobi and other Kantians (Schelling 1980b, pp. 159 and 191n [SW: I, 287-288 and 333n]), ${ }^{53}$ the strategy makes no sense since, once a new field of cognition has been opened up by

51 In an elevated form, of course, that goes beyond the naively dogmatic.

52 The view of the relation of theoretical and practical reason taken here is explained earlier in Vom Ich. Here Schelling observes that 'Kant's theoretical philosophy is not connected with the practical by a common principle. His practical philosophy does not seem to be one-and-thesame structure with the theoretical; instead it seems to be a mere annex to his philosophy as a whole and, what is more, an annex wide open to attacks from the main building' (Schelling 1980, pp. 65-66 [SW: I, 154]). The remedy for this disunity is to translate the practical back into the theoretical, by grasping that practical cognition is non-objectual: 'To be sure, according to Kant, practical philosophy leads into the supersensuous domain because, in its turn, it annihilates everything that is theoretical and reestablishes what is intuited intellectually ...' (Schelling 1980, pp. 99-100 [SW: I, 201-202).

53 Conclusions cannot be drawn from mere needs, and if they are drawn, then they require theoretical support (Schelling 1980b, p. 158 [SW: I, 286-287]). 
an "intensified [verstärkten]" practical reason, theoretical reason has every right to take possession of what has been discovered; indeed, theoretical reason may be regarded as itself transformed by intensified practical cognition (Schelling 1980b, pp. 158-159 [SW: I, 287]). Moreover, the "system of weak reason" fails to refute dogmatism, but merely demonstrates its indemonstrability (Schelling 1980b, p. 164 [SW: I, 295]), leaving dogmatism sufficiently intact to threaten to destroy the practical foundations of the moral theology. ${ }^{54}$ What is needed is a conclusive, prior victory over dogmatism in the theoretical sphere, and this demands that we proceed to a higher point than that of the Critique of Pure Reason. In short, the moral theology demands that we re-engage with questions in theoretical philosophy - in fact, with the highest question of all, that of the existence of the world, the egress of finite beings from the absolute (Schelling 1980b, pp. 164, 174, 177 [SW: I, 294, 310, 313-314]), ${ }^{55}$ which subsumes the lower-level questions of the relation of subject and object, and of the possibility of experience. But it also tells us how those questions should be addressed, namely through a further augmentation of the concept of a practical postulate, which we should now conceive as a "productive realization" on the part of the practical faculty, by which the system of freedom obtains reality (Schelling 1980b, p. 171 [SW: I, 305]): "the theoretical question necessarily becomes a practical postulate" (Schelling 1980b, p. 175 [SW: I, 311]). ${ }^{56}$ And this practical postulate also represents, Schelling claims, Spinoza's true (albeit inadequately expressed) insight. ${ }^{57}$

54 A 'breath of dogmatism would overthrow your house of cards': (Schelling 1980b, p. 161 [SW: I, 290]).

55 As an assertion of the absolute in human knowledge, it is 'groundless' and 'can have no further ground' (Schelling 1980b, p. 173 [SW: I, 308]).

56 Schelling adds an explanation for why reason should appear weak: the 'absolute freedom in you ... makes the intellectual world inaccessible to every objective power' (Schelling 1980b, p. 195 [SW: I, 340]).

57 Spinoza framed his insight, Schelling claims, in terms of merely analytic propositions: (Schelling 1980b, pp. 173-174, 178, 181 [SW: I, 309-310, 315, 319]).

The critique of Kant's moral theology in this text has many elements. I have referred already to (1) the alleged incoherence of the moral theology regarding truth and practical reason, and (2) the allegedly misguided strategy of weakening theoretical reason. Schelling's view is that the relevant properties of cognitive strength - capacity or incapacity to grasp the supersensible cannot be localized to particular 'forms' of reason: if practical reason can grasp the supersensible, then this must be true of theoretical reason as well; practical reason testifies to theoretical reason's capacity to do the same. If the concept of God is not theoretically legitimate, then practical reason is not entitled to employ it (Schelling 1980b, p. 158 [SW: I, 286]). But several other important charges are also laid: (3) To the extent that the moral theology allows itself to be appropriated by dogmatism, this is because it is grounded on what has been conceived in abstract 
4. The favourable and unfavourable treatments of practical postulation that we find in the German Idealists can be regarded as two sides of the same coin. If we look at the series of German Idealist treatments of Kant's moral theology the list of writings I gave at the beginning - we see a progressive reversal of estimate concerning its value. At the outset, in 1792, Fichte endorses the moral theology and extends the scope of the practical postulates that emerge from the antinomy of practical reason to include revelation and transcendental idealism itself. At about the same time Hegel subscribes to the moral theology as a framework for developing his thoughts about religion, morality, and their regeneration. Later Schelling criticizes the detail of Kant's moral theology, dismissing Kant's antinomy of practical reason and the theistic resolution thereof, but proposes an overhauled, Spinozistic version which he claims captures its true spirit. Finally, in the Phenomenology, Hegel declares it a "whole nest" of "thoughtless contradictions" (Hegel 1977a, § 617, p. 374 [HW: III, 452]). ${ }^{58}$ On the account I

terms as a mere method, which as such (like all methods) is necessarily neutral between dogmatism and criticism. The merely methodological conception of practical postulation which is deployed in the moral theology is thus inadequate (see note 124 below). (4) The moral theology is ethically limited and aesthetically null. To posit a 'moral god', a God 'under moral laws', in order to guarantee our indestructibility, is to annihilate the possibility of the sublime; sublimity belongs to tragedy, which allows that we may perish in the struggle with 'the immeasurable'. The positing of a moral god 'keeps the world within bounds', and interposes something between the world and myself, with the result that my intuition of the world is 'restricted', and that the 'abandonment' of myself to the world which marks tragedy - our confrontation with 'the immeasurable' - becomes impossible. Nor is the moral theology compatible with beauty, the proper principle of which is 'reciprocal yielding in contest', again the prerogative of tragedy. Moral theism thus has no 'aesthetic side': it negates the possibility of aesthetic value (Schelling 1980b, p. 157 [SW: I, 284-285]). (5) The moralized conception of God is in any case destroyed once we, having achieved practical cognition of God, reflect on what God's reality involves, namely, the transmoral reality of Spinoza's God sive Nature. Thus Schelling talks of destroying the moral theology once we retrace our steps (Schelling 1980b, p. 160 [SW: I, 289]). (6) The highest good, conceived as 'rewarding happiness', is a 'moral delusion', an incoherent 'assignat' (Schelling 1980b, pp. 183-184 [SW: I, 322-323]). Properly interpreted, the highest good is a beatitude identical with absolute freedom (Schelling 1980b, pp. 184-185 and 187-188 [SW: I, 324 and 328-329]).

Specific criticism of Kant's theological postulates is also contained in Vom Ich (Schelling 1980, pp. 96-97 [SW: I, 197-198]), in Abhandlungen (Schelling 1994, pp. 137-138 [SW: I, 451452]), where Schelling claims that Kant's claims concerning God and immortality fail to qualify as postulates, and in (Schelling 1927-59), which refers scathingly to Kantians who reintroduce by the back door of philosophy what has been expelled from the front, and again insists that deeming a concept a practical postulate cannot circumvent the theoretical question 'nach dem letzten Grund der Realität' (Schelling 1980b, SW: I, 476).

58 Restated in the Encyclopedia Logic, § 60 (Hegel 1975, pp. 90 -91 [HW: VIII, 141-142]). 
have suggested, this may be seen as a matter of using, and finally kicking away, a philosophical ladder: once everything necessary had been extracted from Kant's moral theology, there remained nothing to say about Kant's practical postulates beyond indicating how they fall short of the desiderata of systematic unification which they themselves implied, and which the new post-Kantian idealism claimed to meet.

This conception of the moral theology as defining the conditions of adequacy for post-Kantian idealism is reflected in the way that it recurs in the internecine strife of German Idealism. Schelling and Hegel, in the Differenzschrift of 1801 and Kritisches Journal essays of 1802 (Schelling 2000, pp. 371-374 [SW: V, 112-117]), ${ }^{59}$ deploy against Fichte objections which follow closely the pattern of those that had been put a decade previously to Kant's moral theology - Fichtean idealism is, in effect, charged with reproducing its incoherences in magnified form..$^{60}$ The theme returns in the late Schelling's Hegel critique: Hegel's "pure-rational" philosophy, Schelling maintains, grinds to a halt at exactly the same point as Kant's postulate of God's existence, that is, before the transition has been made from mere ideation to actual existence. ${ }^{61}$

6. To recapitulate, and to return to the material discussed in the first part of this paper, we can see how, under pressure from the two objections to the moral

59 The charge that Fichte's idealism reproduces the limitations of Kant's philosophy as displayed in the moral theology is made in (Schelling 1984, p. 22 [SW: IV, 326]), and (Schelling 1988, p. 54 [SW: II, 72]): the validity of subject-object identity is restricted by Fichte to subjective consciousness, and the absolute is reduced to the mere 'object of an endless task, an absolute demand'; Fichte, like Kant, excludes absoluteness from speculation and seeks to reconnect it with the deepest subjectivity only through action and faith; Schelling refers to passages in the Grundlage where Fichte identifies absolute unity with the object of an Idea understood merely as 'something that ought to exist'.

60 Schelling, letter to Fichte, 3 October 1801 (Frank/Kurz 1975, p. 162): 'in order to uphold your system, one must decide at the outset to proceed from Seeing [Sehen] and to have no more to do with the Absolute (the truly speculative), roughly in the way that, in Kantian philosophy, the moral law must come first and God last, if the system is to hold up' (my translation).

61 In passages from the late Philosophy of Revelation, Schelling returns to Kant's postulate of God's existence. This he now interprets as a demand 'for an extension' of philosophy which Kant was unable to follow through: lacking any concept of theoretical philosophy that is not that of a 'mere science of reason', Schelling says, Kant was forced to conceptualize it as a demand that 'only had significance for action [die Praxis]', whereas its true and proper fulfilment lies in 'positive philosophy' (Schelling 2007, p. 191 [SW: XIII, 146]). Schelling directs this same point against Hegel, whose 'rational', 'pure-rational' philosophy reproduces the limitations of a subjective moral need ('subjektive oder moralische Notwendigkeit') which demands the reality of God in a form (namely: as 'das Überseiende') which it cannot accommodate (Schelling 1977, p. 135). 
theology, Kant's problematic notion of practical postulation evolves in German Idealism in three stages:

(i) In Fichte's Jena Wissenschaftslehre, the concept of a postulate remains practical in Kant's sense of invoking the principle of the primacy of practical reason, but it is, crucially, disconnected from the highest good and antinomy of practical reason analyzed in Kant's second Critique. This is shown by the way in which, we saw, Fichte in the Wissenschaftslehre nova methodo identifies what he calls "Kant's postulate" - in the singular - not with any proposition or doctrine sanctioned by the principle of the primacy of pure practical reason, but with that principle itself.

(ii) Then, in the move from the Jena to the 1804 Wissenschaftslehre, postulation remains thought through and as Sollen, but the subject of obligation - that which soll - is no longer the Ich, but being - the absolute - itself. The Sollen in application to the absolute no longer has a determinately moral character. Fichte thereby brings himself partially into line with Schelling, but remains separated from him by his insistence that Sollen provides the exclusive route to, and is equiprimordial with, absolute Seyn.

(iii) In Schelling's conception, the Sollen is side-lined, in so far as it is adduced merely in order to provide the basis on which we are entitled to postulate the universal validity of our intellectual intuition. This might seem to make Schelling's notion of postulation theoretical rather than practical, but he continues to affirm also its intrinsic practical significance, and this is readily intelligible, since it is for Schelling an expression - and not a representation - of freedom: Schelling's absolute postulate supplies the immediate ground of moral consciousness, which it therefore implicates.

The resulting notion, whether we take Fichte's version or Schelling's, preserves all three of the original Kantian features - rationally necessary cognition, which reflects the standpoint of reason as a whole, and realizes its highest ideas with the differences that, because postulation has been released from its subservience to the highest good, the first objection is disarmed - philosophy's postulates are conceptually autonomous, not instrumental - and the ontological ambiguity has been removed - the existential commitment is unequivocal.

Fichte and Schelling's positions, as they stand at the end of this development, can of course be stated without reference to Kant's moral theology, but this eventual conceptual independence does not detract from the fact that the development and formulation of the notion of absolute postulation was undertaken in light of their perception of the philosophical potential of Kant's practical postulates. If we want to locate the point where German Idealism comes closest to explicitly acknowledging this debt, while at the same time affirming the selfsufficiency of the newly developed notion and its ultimate conceptual independ- 
ence from its Kantian ancestor, then the place to look is Hegel's Differenz essay and Glauben und Wissen. ${ }^{62}$

\section{Contrasting post-Kantian developments}

In order to throw into relief the distinctive way in which Fichte and Schelling pursue Kant's conception of practical postulation, we may contrast their treatments of the practical postulates and moral theology with those of three other post-Kantians, namely Jakob Sigismund Beck, Jakob Friedrich Fries, and Novalis.

62 See the account of Kantian faith as reflection's relation to the Absolute (Hegel 1977b, p. 100 [HW: II, 31-32], and (Hegel 1977, pp. 94-96, 156, 178, 187 [HW: II, 329-332, 395-396, 418-419, 428-429]) - moral faith is recognized as the highest point reached in the Kantian system, the point where it comes closest to the Absolute. This assessment endured: in a letter to Duboc, 30 July 1822, Hegel writes: 'However, besides the other merits of the Kantian philosophy, I still wish to point out how interesting and instructive it is to see in Kant's so-called postulates not only the necessity of the Idea but also the more precise definition of it' (Hegel 1984, p. 492 [Briefe, Bd. II, 1813-1822, no. 422, p. 327]). In the 'Postulates of Reason' section of the Differenzschrift (Hegel 1977b, pp. 111-112 [HW: II, 42-44]), which follows the discussion of transcendental intuition, Hegel exhibits a complex ambivalence regarding the concept of a postulate: the Idea itself cannot be postulated, but its intuitional complement is postulated by Reason, yet not in opposition to the Idea, though 'this whole manner of postulating' is also, viewed from another angle, merely due to the fact that one-sided reflection has been taken as a starting point, the effect of which is distorting, since reason thereby appears 'needy'. The upshot, I suggest, is that when Hegel describes Reason, liberated from reflection, as 'positing absoluteness', 'both Idea and Being', he might just as well have called it an absolute postulate. It is noteworthy, in this connection, that in the Lectures on the Philosophy of Religion Hegel affirms that religious consciousness proceeds, as Kant and Fichte maintain, via the necessity of a presupposition, while insisting that this presupposition is not merely subjective; its appearance as merely 'the activity and so forth' of the subject is only one 'moment' (Hegel 1824, pp. 212-214 [HW: XVII, 269-270]).

Hegel's position in these texts, from 1801 and 1802, is related to the intellectual development exhibited in the Jugendschriften in the following way: In the course of the 1790s, after initially affirming the unqualified adequacy of Kant's moral theology in the 1793 Tübingen essay on religion (Hegel 2002), Hegel discovers the problem (as he perceives it) that Kant is stuck with a flat opposition of Ought to Is. This problem is made explicit in the later Spirit of Christianity text (Hegel 1996), but at this point Hegel either does not perceive it as a deep metaphysical problem in its full generality or is without the means to address it. Schelling's identity philosophy provides Hegel with this means, allowing him in the 1801-02 essays to reject the moral theology from a standpoint that has surpassed it. 


\subsection{Beck}

Beck's proposal is that Kant's theory of empirical knowledge be construed as a theory of postulates, and even more fundamentally, that the very transcendental Standpunct of Critical philosophy itself be regarded as defined by and around a single postulate, of what he calls “original representing”, ursprüngliche Vorstellen. On Beck's account, the application of the categories - in for example the subject-predicate synthesis, whereby something permanent is posited as underlying the empirical manifold - presupposes (indeed, consists in) an "activity [Handlung] of objective relation”, “original attribution [ursprüngliche Beilegung]”, “original procedure (or use) of the understanding [ursprüngliche Verstandesverfahren]". This activity, whereby the category of for example substance is given application, is one that, we discover, must be performed if we are to satisfy the imperative "Conceive of being presented with an object!" or "Produce the synthetic unity of consciousness!" or "Represent originally!"63 The categories are thus reconstrued as determinate functions realized in acts, as modes of Vorstellen as opposed to Vorstellungen, our consciousness of which is what gives our representations objective reference (and at the same time generates the "I think" of the objective synthetic unity of apperception). By treating application of the categories on the model of a geometer's acts of mental imaging in compliance with postulates, Beck aims to give transcendental claims the same degree of certainty and perspicuity.

Beck's early letters to Kant suggest that he was motivated originally to develop this theory by the difficulties that he considered created by Kant's definition of intuition in terms of "immediate relation to an object", which, Beck supposes, contradicts the Transcendental Deduction's claim that the categories are necessary for objectivity. ${ }^{64}$ Beck's full view, however, which he develops in two books in $1796,{ }^{65}$ is that recognition of an original use of the understanding in "original representing" is strictly required for a correct understanding of all core Kantian notions - including the absolutely basic notion of "the possibility of experience", as Critical philosophy understands it - and that without it Kantianism becomes dogmatic. Dogmatic Kantianism is what results when transcendental phi-

63 'Stelle ursprünglich vor!', (Beck 1796b, §9). These are alternative but according to Beck equivalent formulations of the Postulat.

64 And not in the first instance, although this comes immediately to the fore, the problem of the thing in itself.

65 Expounded in (Beck 1796a) and (Beck 1796b) and neatly summarized in his letters to (Kant: 17 June 1794, no. 630, [AA 11:509-511]) (Kant 1999, pp. 479-480), and (20 June 1797, no. 754, 12:164-169) (Kant 1999, pp. 512-515). 
losophy is construed as a matter of discursive proof-giving, a methodology which is futile - since it leaves us with mere shells of philosophical concepts, to which no real sense or meaning attaches - and which provokes a new skepticism (which it is unable to answer). The presentation of the theory of experience in the Critique of Pure Reason follows a dogmatic route, Beck allows, but it does so only for heuristic purposes, in letter but not in spirit; Kant was obliged to begin within his readers' "dogmatic cast of mind", in order to lead them out of it (Beck 1796b, §71).

Though his own intentions were limited to overhauling the exposition of Kant's theoretical philosophy without any alteration of its teachings, with a view to rendering it consistent and immune to skeptical attack, Beck's theory of a postulate of original representing departs from Kant in important, indeed, proto-Fichtean ways. ${ }^{66}$ But while in some set of terms Beck's theory counts as a radical innovation, his employment of the concept of a postulate goes beyond that of Kant in the Postulates of Empirical Thought in only a limited respect. Kant claims in the Postulates chapter that the objective application of modal concepts involves a reflective, second-order appraisal of previously given objective cognitions: to say that an object is possible is to judge that the cognition of it is consistent with the principles of possible experience (Beck 1796b, §§ 49-52). Beck preserves this idea: to say that a certain category is necessary for experience is to say that the corresponding act must be performed if there is to be objective representation. The key element that Beck adds is the notion that, in order to undertake such an appraisal, it is necessary to occupy the standpoint of objectrepresentation in a non-discursive, proto-phenomenological sense: Beck talks of the necessity of transposing ourselves ("sich versetzen") into the situation wherein all experience is generated. ${ }^{67}$ In so doing Beck draws the Kantian sense of postulate back to its Euclidean root: in place of the mere analogy that Kant implies of the principles which govern the use of modal categories with the postulates of Euclid, Beck envisages geometrical cognition as a sub-instance of the very same kind of postulate-based cognition as, on his account, constitutes transcendental philosophical knowledge in general. ${ }^{68}$

66 Note that, whether or not Beck's account eliminates sensation and sensibility in Fichtean fashion - the charge levelled by Schulz - and whether or not it improves Kant's situation overall, Beck (i) deprives Kant of his preferred retort to the charge of Berkeleyanism, and (ii) undercuts the non-empirical employment of the categories that Kant wishes to preserve.

67 'Ich ... suche meinen Leser in die Handlung selbst zu versetzen'; letter to Kant, 17 June 1794, no. 630 (Kant 1999, p. 480 [AA 11:510). And see (Beck 1796b, §91).

68 '... this production of the synthetic unity of consciousness "the original attribution [ursprüngliche Beilegung]". It is this activity, among others, that the geometer postulates when he starts 
Beck's notion of a postulate of original representing is thus clearly different from the notion of practical postulation employed in the moral theology. Indeed it might well be thought that on Beck's terms there could not be postulates in the sense of the moral theology, since postulation is tied by Beck to an object's being given in the synthetic unity of apperception, and the practical postulates certainly do not give objective reality to ideas of reason in that way. But in fact, and surprisingly, this is not what Beck says. Instead, Beck draws up an account of practical reason in an attempted parallel with his account of theoretical reason, maintaining that there is also a postulate of an "original use" of practical reason, whereby we conceive ourselves as non-natural causes capable of determining our wills independently of all natural influence. (Beck 1796b, Part II, §§ 208233) The obvious problem with this strategy - which is forced on Beck by his agreement to follow Kant in matters of morality and religion, rather than handing them over to the Glaubensphilosophen - is the absence of any common feature, beyond the mere title, of the original theoretical and practical postulates: Beck gives no clue as to how an original act of the practical faculty can give rise to, or yield knowledge of, our existence as extra-empirical agents, in the way that an original act of the understanding can allow objects to be given. If practical postulation parallels theoretical postulation, then free causality ought to be phenomenologically immanent - which would convert practical reason into intellectual intuition (as well as undercutting Kant's identification of freedom with morality). ${ }^{69}$

his geometry from the proposition "Conceive of space"; and no discursive representation whatsoever could take its place for this purpose. As I see the matter, the postulate "To conceive of an object by means of the original attribution" is also the highest principle of philosophy as a whole', Beck to Kant, 17 June 1794, no. 630 (Kant 1999, pp. 479-480 [AA 11:509]). Note that Beck's concept of postulate, as my account has revealed, involves two separable elements: the (single) imperative that defines transcendental reflection and which demands a pre-discursive act (postulates as per Euclid), e. g., 'Represent an object!', which as Beck says (Beck 1796b, $\S 8$ ) cannot be equated with a hypothesis; and the (plural) non-imperatival, theoretical, discursive principles that transcendental reflection leads us to grasp (postulates as per Kant's Postulates of Empirical Thought). The latter are discussed in some detail in (Beck 1796b, §§ 49-52). The connection of the two senses is nonetheless clear: postulates-as-principles are what result from the dissection and exhibition (Beck 1796b, § 9) of the original use of the understanding which the imperatival postulate commands.

69 The result is massively revisionary of Kant in several respects. If Beck is right that extra-natural freedom is involved in practical reason, then it must be epistemically prior to morality perhaps in agreement with the Groundwork of the Metaphysics of Morals, Pt. III, but contra the Critique of Practical Reason. This indeed seems to be acknowledged, since in (Beck 1796b, $\S 215)$, Beck makes the Formula of Universal Law the expression of freedom, hence, presumably, epistemically derived from our knowledge of our freedom. Second, if Beck were correct, then 
What Beck has specifically declined, with his attempted parallelism of theoretical and practical postulates, is the distinctive ambition of Kant's notion of a practical postulate to straddle the two spheres. It is no accident, therefore, that in Beck's own exposition of Kant's moral theology, no mention is made of postulates, and the distinctive and complex character of Kant's theological postulates, with all of the problems that surround them, gives way to the plain and simple identification of religious belief with hope, or an attitude of mere confidence that one will achieve one's moral goal. ${ }^{70}$ Schelling's critique of Beck, in the 1797-98 Abhandlungen (Schelling 1994, pp. 112-119 [SW: I, 135]), ${ }^{71}$ accordingly highlights and takes issue with the conservative character of Beck's revision of the concept of a postulate, which leaves the operations of the Verstand disjoined from the Ideas of Vernunft, and the latter outside the scope of theoretical cognition.

\subsection{Fries}

The interest of Fries in the present context lies in his showing how, while accepting the central thrust of Jacobi's critique of Kant's moral theology and of Critical philosophy in general, one might nevertheless attempt to rescue the Kantian system in the service of theistic ends. Fries aims to broker a reconciliation between

prima facie we would have cognition of ourselves as intelligible causes, and this would count as a piece of theoretical knowledge (it would be 'practical' only in the sense of being facilitated by willing). Beck attempts to head off this implication by saying that although we thereby conceive ourselves as intelligible entities with an intelligible character, 'all conception of the intelligible escapes us and is unintelligible’ (Beck 1796b, § 217). But this is hard to understand: if an original use of understanding yields intelligibility, why should an original use of practical reason not do so? Again, Beck says in (Beck 1796b, § 228) that the concept of freedom has 'no theoretical, objective validity', because it is 'only an original use of reason', which has 'no original use of understanding for a basis', but it is hard to understand why it should need to have such a basis. In (Beck 1796b, § 214) Beck draws an analogy with the transcendental unity of apperception, but does not say what 'the original unity of practical reason' amounts to.

70 Beck says in (Beck 1796b, § 240) that the agent's supposition that he will attain his end of achieving a holy will and that nature will be consonant with a moral order leads him to believe in God, but that this belief does not connect with theoretical judgement, since it is nothing but a confident hope (Beck 1796b, § 241). In (Beck 1796b, § 249) Beck asserts that belief in God and immortality, resting on a morally good disposition aiming at a moral world-order, constitutes religion and favours morality, but leaves it unclear whether he follows Kant's moral proof.

71 Schelling objects that (among other things) Beck's postulate of primordial representation is merely theoretical and rests on a concept that it cannot make intelligible, viz. that of primordial representation (Schelling 1994, p. 118 [SW: I, 423]), and 'leaves practical philosophy without any foundation' (Schelling 1994, p. 121 [SW: I, 427]). 
Kant and Jacobi, by recruiting Kantian resources to the defence of a philosophy of Glauben - to meet the demands, which Jacobi repudiates, of Wissenschaft, by giving a wissenschaftlich account of Glauben itself.

Fries takes it as given, in light of the criticisms of Schulze and Maimon, that in general so-called transcendental proofs prove nothing of ontological import: the Analogies of Experience for example show only that human reason has the need to presuppose, das Bedürfnis vorauszusetzen, the truth of their principles (Fries 1828, pp. xvii-xviii). ${ }^{72}$ Kant's so-called moral proofs of the theological ideas are, in parallel, no more successful in getting us beyond mere necessities of representation: the arguments rest on the presupposition of moral consciousness, the necessity of which has merely factical, psychological status, and in any case they merely lead us in a circle (because, Fries claims, they show God, freedom and immortality to be in turn presuppositions of the validity of the moral law). ${ }^{73}$ But instead of following Jacobi in rejecting wholesale the Critical endeavour, ${ }^{74}$ Fries infers that transcendental enquiry should be reconstrued as what he calls "philosophische Anthropologie", that is, in the first instance, empirical psychology. What Kant's misunderstanding of his deductions as proofs brings us to see, Fries claims, here following Jacobi, is Kant's perpetration of the rationalist dogmatic "prejudice", Vorurtheil, that cognition presupposes proof. Once this prejudice is overcome, we are able to return with full confidence to the immediate convictions of natural consciousness, and these include, per Fries, the truth of Kant's practical postulates: "we defend the rights of belief [Glauben] primarily by showing that knowledge, too, arises only subjectively in reason” (Fries 1989, p. 69).

Fries' reconstruction of the Critical philosophy salvages therefore a large quantity of Kantian doctrine, including Kant's theism, while sacrificing entirely its foundations. This, on Fries' view, is the proper lesson to be learnt from Jacobi's critique of Kant. The practical postulates are absorbed into sub-spheres of immediate cognition, initially into the province of Glauben and subsequently into the sphere of affective or aesthetic cognition that Fries calls Ahnung. Kant's insight that moral consciousness provides sufficient attestation of the re-

72 See also (Fries 1812, pp. 31-37) on Kant.

73 In Wissen, Glaube und Ahndung, Fries rejects the arguments that Kant gives for the theological postulates on a number of grounds. In the chapter 'On the Eternal Good' (Fries 1989, pp. 83-87). Fries describes the religious beliefs that Kant recommends as psychologically impossible, rejects Kant's formulation of the highest good, and denies the coherence of supposing infinite time to be sufficient for the attainment of complete virtue; later he rejects the priority of freedom over the theological postulates (Fries 1989, p. 90).

74 See Fries' criticisms of Jacobi in (Fries 1812, pp. 38-53). 
ality of the supersensible objects is generalized to all purely intellectual representations, and the propositions in Kant's theological postulates are upheld in a form which renders them immune to the objections levelled against Kant's moral theology, since Fries has abandoned the attempt to derive them from an antinomy of practical reason.

\subsection{Novalis}

The concept of practical postulation allows us to also specify the parting of ways within the post-Kantian development of the Romantics from the systematic idealists. This is clearest in Novalis. ${ }^{75}$

Novalis arrives through reflection on Fichte at the idea that intentional, propositionally articulated consciousness is dependent on a source which can come before us only in the shape of feeling. Whereas Fichte supposes it possible to step behind the scenes of natural consciousness and reverse its inverted image of reality, Novalis relinquishes the idea that we can achieve a cognitive grasp, of the sort claimed by Fichte, of the non-conscious ground of our subjectivity. Our proper relation to this absolute ground, after we have freely renounced it from the standpoint of cognition, ${ }^{76}$ Novalis conceives instead in terms of activity the activity of, as he puts it, seeking "connection [Verknüpfung]" with the whole, "enlargement [Verganzung]", of the subject's compass to a whole.

What Novalis has in mind by enlargement-and-connection-to-a-whole is the Romantisierung der Welt, which includes theoretical enquiry into nature - in appropriately naturphilosophisch forms - but only as a subsidiary component. It is not, therefore, equivalent to the extension of our cognition to the whole of nature, on the model of the Kantian understanding. ${ }^{77}$ Nor, however, is it practical in the usual sense, since it consists not in our changing the world, but in our being changed by the world. Novalis says that we thereby manifest "the absolute ground of all grounding", the "freedom" in the ground, and become aware of our own "absolute freedom". This awareness, and the activity which makes it possible, constitute furthermore a negative cognition of the absolute ground, which is given to us "insofar as we act and find that what we seek cannot be attained

75 I focus on a key passage from the Fichte Studies, Group V, no. 566 (summer 1796): (Novalis 2003, pp. 167-168).

76 After 'interruption of the drive towards knowledge of the ground' (Novalis 2003, p. 168). 77 Novalis talks of extending understanding through imagination, 'Der durch die Einbildungskraft ausgedehnte Verstand' (Novalis 2003, p. 168). 
through action": the "negatively known absolute" is "known through action" (Novalis 2003, p. 168). ${ }^{78}$

Finally, Novalis says that all of this "could be called an absolute postulate", and we can see why he does so. Romanticization is positioned, as we have just seen, mid-way between theoretical and practical reason. In addition, Novalis explains that he is offering the postulate of enlargement to a whole in place of "searching for a single principle" (which he compares to the attempt to square the circle). Since Novalis is thinking here of postulates as alternatives to principles, we might ask what the difference is - why cannot a proposition be both, as Fichte and Schelling assume. ${ }^{79}$ The answer is that Novalis also thinks, as other passages in the Fichte-Studien make clear, that practical existence, when it achieves its higher (that is, romantic) forms, exceeds what can be comprehended. ${ }^{80}$ Fichte thinks that the act which his absolute postulate enjoins can be grasped by philosophical reason - it can be observed, and modelled systematically in the Wissenschaftslehre. This is what Novalis denies. Novalis must of course agree that an imperative can point us in the direction of the required activity - I can think: Let me connect myself to the whole! - but the forms of activity which might satisfy the imperative cannot be determined discursively, any more than the concept of a work of art can determine the objects which satisfy it. The concept of an absolute postulate marks then, for Novalis, an exit point for philosophical reflection, not, as in Fichte and Schelling, the highest point within it. ${ }^{81}$

78 Novalis concludes the passage: 'Thus eternity is realized temporally in spite of the fact that time contradicts eternity' (Novalis 2003, p. 168). A model for this conception of infinite approximation to an end as equivalent to its ultimate realization is contained in Kant's moral theology, where it is claimed that our infinitely extended, posthumous striving to achieve holiness of will can be taken - by God - to count as its realization. The fact that Novalis compares negative practical cognition of the absolute ground with achieving eternity through time implies his awareness of this connection. See also (Novalis 2003, no. 54, pp. 38-39), concerning Kant's postulates, practical striving, and duration. For detailed discussion of the practical and aesthetic in Novalis, see (Kneller 2007).

79 In (Fichte 1992, p. 109 [FW/GA: IV, III, 343-344]), Fichte objects to J. S. Beck, who maintains a first postulate rather than a first principle, that he misconceives principles. (Schelling 1994, p. 112 [SW: I, 414]), affirms that the Grundsatz of self-determination is a postulate.

80 See (Novalis 2003, no. 89, p. 46), where Novalis says that 'the practical I' is only a 'postulate' of the 'theoretical I': we represent the practical I, and this representation is formed by taking the idea of the theoretical I and qualifying it as 'practical'; it 'borrows' the idea of the unconditioned, the purely free. The genuine practical I escapes representation and has only one expression: it 'commands pure and simple'. As soon as we reflect on its efficacy, it is found to be theoretical.

81 What Novalis is proposing really amounts to, then, is the (extraordinary and striking) thought that our lives - when lived romantically - are the solution to the basic problem of tran- 
The same idea of transcendental questions as resolving themselves into problems of modes of living, and as receiving their answers in special forms of human life, and in aesthetic forms, is present in Hölderlin. ${ }^{82}$ In this sense it is the German Romantics - and not, we saw, Fichte - who pursue the primacy of the practical to its ultimate conclusion.

\subsection{The contrast}

For all of their considerable differences, Beck, Fries, and Novalis share common ground. Beck and Fries both proceed from the view that Kant's deductions, as they stand, fail in their objective of furnishing proofs for transcendental propositions, and their respective proposals to repair Kantian epistemology proceed from this point: Beck aims to save transcendental proof by modelling it more closely on geometrical demonstration, and Fries to rescue transcendental claims by grounding them on facts of inner awareness. Analogously, Novalis regards

scendental philosophy. So transcendental philosophy resolves itself into the task of living: not in the way that Kant thinks that pure reason finds its fulfilment in moral living, but in the way that Jacobi thinks philosophy leads us to leap outside it. But even if, in one sense, Novalis brings transcendental philosophy down to earth, it is to be remembered that the mode of living which provides the answer to the transcendental question is at the same time raised up: it is romantisch, transcendentalized living.

82 Hölderlin conceives the tragic as 'the metaphor of an intellectual intuition' (Hölderlin 2009a, p. 68 [Sämtliche Werke, Bd. IV.1, p. 266]). See also the Vorrede to Hyperion, Vorletzte Fassung, concerning beauty as the presence to us of Being in its true sense (Hölderlin 1957, pp. 236237), and (Hölderlin 2009b), concerning the poet's realization of the necessity of striving and of conflict between two postulates, and the idea of 'pure poetic life'.

Hölderlin's exact view of the relation of the aesthetic to the practical is not easily determined, but it is clear at any rate that Hölderlin's aesthetic turn is directly continuous with his interest in Kantian practical postulation. Hölderlin rehearses and endorses the whole of the argument of Kant's moral theology in a letter to his half-brother, Karl Gok, 13 April 1795 (Hölderlin 2009, pp. 49-5) and (Hölderlin 1954, no. 97, pp. 162-164), and the letter in which he famously talks of infinite approximation as an aesthetic matter comes only a few months later to Schiller, 4 September 1795; (Hölderlin 2009, p. 62) and (Hölderlin 1954, no. 104, p. 181). The idea of a continuous development from moral postulation to the aesthetic, as the 'highest act of reason', is found also in the roughly contemporaneous Oldest System-Programme. Hölderlin's letter to Niethammer, 24 February 1796, talks of 'making the conflict disappear, the conflict between the subject and the object, between our selves and the world, and between reason and revelation,- theoretically, through intellectual intuition, without our practical reason having to intervene' (Hölderlin 2009, p. 68) and (Hölderlin 1954, no. 117, p. 203), which recalls the conception of absolute postulation in Schelling, with whom Hölderlin reports a recent meeting in the following paragraph. 
Fichte's post-Kantian epistemology as unsuccessful, and invokes an affective or aesthetic substitute for the sought-after single principle. In all three cases, then, the proposed revisions involve a rejection of the requirement of discursive demonstration.

The turn to non-discursivity has implications for the treatment of the relation between the theoretical sphere of understanding and the practical sphere of reason. The connection between the two is supplied on Beck's account, we saw, by a mere thin parallel between theoretical and practical postulation, while Novalis envisages theoretical cognition as yielding at its limit to an aesthetic practice. Fries, by contrast, construes nature - apprehended as beautiful or sublime - as an indeterminate Darstellung accessible to aesthetic feeling ( $A h$ nung) of the reality that we attempt to grasp by means of the ideas of reason. This preserves more of the structure of the Critical system - Fries at least agrees with Kant concerning the existence of a third category, intermediate between the theoretical and the practical - but it involves no conception of their unity and to that extent leaves the two spheres fundamentally distinct. Beck, Fries, and Novalis are therefore all united in abjuring the augmented sense of practical postulate, the notion of a single discursive claim which expresses the unity of the theoretical and practical reason, or of Verstand and Vernunft. In terms of the historical narrative that I am pursuing, these three thinkers represent points where (respectively) the concept of a postulate, the moral theology, and the conception of the practical as outstripping the theoretical, become central to post-Kantian philosophy, but in a way which does not conform to the philosophical strategy implied by the augmented concept of a practical postulate, and so they disembark from the German Idealist line of post-Kantian development.

The final observation to make is that Beck and Fries, whether or not their proposals succeed in resolving some of the problems facing Kantian epistemology, make no progress in resolving the problem, highlighted by criticism of the moral theology, concerning our need for assurance of the objective reality of ideas of reason. Beck clearly cannot provide this, for the reason given (and indeed he does not pretend to do so), and Fries' invitation to regard felt conviction of the reality of the ideas of reason as immediate cognition makes no obvious advance on Jacobi's salto mortale. ${ }^{83}$

83 The precise problem reveals itself when the following question is raised: Granted Fries' account of how we come to form ideas of reason, namely through negation of the relational character of the spatio-temporal objects of our Wissen, how do we come to suppose them to have objective reference, i.e. to believe in their reality? The difficulty for Fries lies in reconciling (i) his commitment to explanation of all cognition in terms of subjective powers and processes (as per Kant, and as required by philosophische Anthropologie), with (ii) his affirmation of the 


\section{Conclusion}

The preceding discussion has some bearing on the dispute concerning the metaphysical or non-metaphysical character of German Idealism.

Dieter Henrich has identified the long term historical importance of Kant's doctrine of postulation with (first) its contribution to the theological tradition which seeks to grasp God not metaphysically but through inner revelation, and (second) its role in the prehistory of pragmatism, laying the ground for Feuerbach and Nietzsche (Henrich 1960, pp. 187-188 note 1). This points to a sharp contrast with the German Idealists' reception of Kant's doctrine, where, despite the repudiation of Kant's theism, what stands out is the maintained connection of practical postulation with the Ideal of Pure Reason. As I have tried to show, while it is quite true that Fichte and Schelling detach the concept of a practical postulate from Kant's theism, they do not thereupon convert it into a mere general principle of rational belief in the manner of pragmatism. ${ }^{84}$ Fichte and Schelling instead took Kant's moral theology as an incomplete model or preliminary sketch for a systematic structure intended to complete a metaphysical task with a distinctly early modern flavour, viz., the task of conceptually determining final ontological grounds. If we formulate the puzzle of German Idealism, as is often done, in terms of the question how the German Idealists could have considered it possible to restore metaphysics in the wake of Kant's Copernican revolution, the German Idealists' reception of Kant's moral theology helps us to see how it should be answered. In the perspective of Fichte and Schelling, it was never an option to hold apart the theory of rational belief from ontological commitments: to have negatively circumscribed the task at hand - to have defined philosophical reflection as concerned with epistemic and practical norms in opposition to metaphysics - would have led to the problems acutely visible in

objective reference of ideas of reason (as per Jacobi). The problem arises, therefore, even when Fries is allowed his claim that it is a mistake to aim at a discursive proof of objective reference. Fries is acutely aware of the difficulty - see (Fries 1989, pp. 70, 74-75) - for if it is not resolved, then Fries either falls prey to the objections levelled by Jacobi against Kant, or has added nothing to Jacobi.

84 Schelling explicitly rejects the sufficiency of a methodological conception in the Fifth of his Philosophische Briefe (Schelling 1980b, pp. 168-171 [SW: I, 300-305]). His target comprises ('anxiously modest') Kantians who suppose that 'it is precisely the exclusive use of practical postulates that distinguishes the critical philosopher'. Schelling counters that, in general terms, method is precisely what is shared by opposing systems, and that when practical postulation is conceived as mere method, it does not contradict dogmatism but rather facilitates its renewal. 
Kant's moral theology; what this portion of the Critical system showed above all, in their eyes, was the necessity of completing metaphysical enquiry. ${ }^{85}$

\section{Bibliography}

[FW] Fichte, Johann Gottlieb (1845-46): Johann Gottlieb Fichtes sämmtliche Werke, 8 Bde. Fichte, Immanuel Hermann (Ed.). Berlin: Veit \& Comp. and Fichte, Johann Gottlieb (1834-35): Johann Gottlieb Fichtes nachgelassene Werke, 3 Bde. Fichte, Immanuel Hermann (Ed.). Bonn: Adolph-Marcus.

[FW/GA] Fichte, Johann Gottlieb (1964-): Gesamtausgabe der Bayerischen Akademie der Wissenschaften. Lauth, Reinhard/Jacob, Hans/Gliwitzky, Hans (Eds.). Stuttgart-Bad Cannstatt: Frommann-Holzboog.

[HW] Hegel, Georg Wilhelm Friedrich (1970): Werke. Auf der Grundlage der Werke von 1832-1845 neu edierte Ausgabe. Moldenhauer, Eva/Michel, Karl Markus (Eds.). Frankfurt am Main: Suhrkamp.

[SW] Schelling, Friedrich Wilhelm Joseph von(1927-59): Schellings Werke. Nach der Originalausgabe in neuer Anordung. Schröter, Manfred (Ed.). München: Beck.

Adorno, Theodor W. (1973): Negative Dialectics, London: Routledge \& Kegan Paul.

Ameriks, Karl (2000): “Kant, Fichte, and the Radical Primacy of the Practical”. In: Kant and the Fate of Autonomy. Cambridge: Cambridge University Press, pp. 187-233.

Beck, Jakob Sigismund (1796a): Einzig mögliche Standpunkt aus welchem die kritische Philosophie beurtheilt werden muß. Riga: Hartnoch.

Beck, Jakob Sigismund (1797): The Principles of Critical Philosophy. London: J. Johnson/W. Richardson/Edinburgh: P. Hill/Manners and Miller/Hamburg: B. G. Hoffmann.

Breazeale, Daniel (2004): '"Wishful Thinking'. Concerning Fichte's Interpretation of the Postulates of Reason in his Versuch einer Kritik aller Offenbarung (1792)". In: Philosophy and Religion in German Idealism. Ernst-Otto Onnasch/Willian Desmond/Paul Cruysberghs (Eds). Dordrecht: Kluwer, pp. 35-70.

Düsing, Klaus (1999): “The Reception of Kant's Doctrine of Postulates in Schelling's and Hegel's Early Philosophical Projects”. In: The Emergence of German Idealism. Daniel 0. Dahlstrom/Michael Baur (Eds.).Washington, D.C.: Catholic University of America Press, pp. 201-237.

Eberhard, Johann August (1793): “Dogmatische Briefe, 18-30”. In: Philosophisches Archiv 1 (4), pp. 46-90.

Eberhard, Johann August (1799): Ueber den Gott des Herrn Professor Fichte und den Götzen seiner Gegner. Eine ruhige Prüfung an das Publikum in einigen Briefen. Halle: Hemmerle und Schwetschke.

85 I am very grateful to members of the audience at the University of Aarhus, the University of Sydney, and the Oxford Post-Kantian Seminar, where earlier versions of this paper were presented, for comments and suggestions. 
Fichte, Johann Gottlieb (1962): "Versuch eines erklärenden Auszug aus Kants Kritik der Urteilskraft”. In: J. G. Fichte: Gesamtausgabe. Reihe II, Vol. I. Hans Jacob/Reinhard Lauth (Eds.). Stuttgart-Bad Cannstatt: Frommann-Holzboog, pp. 324-373.

Fichte, Johann Gottlieb (1971): Die Wissenschaftslehre, in Fichtes sämtliche Werke. Bd. X. Berlin: Walter de Gruyter, pp. 315-492.

Fichte, Johann Gottlieb (1971a): “Eigene Meditationen über ElementarPhilosophie”, in J. G. Fichte: Gesamtausgabe. Reihe II, Vol. III. Hans Jacob/Reinhard Lauth (Eds.). Stuttgart-Bad Cannstatt: Frommann-Holzboog, pp. 1-177.

Fichte, Johann Gottlieb (1971b): “Praktische Philosophie”. In: J. G. Fichte: Gesamtausgabe. Reihe II, Vol. III. Hans Jacob/Reinhard Lauth (Eds.). Stuttgart-Bad Cannstatt: Frommann-Holzboog, pp. 179-266.

Fichte, Johann Gottlieb (1978): Attempt at a Critique of All Revelation. New York: Cambridge University Press.

Fichte, Johann Gottlieb (1982): “Foundations of the Entire Science of Knowledge”. In: Fichte, The Science of Knowledge, with the First and Second Introductions. Peter Heath/John Lachs (Ed.). Cambridge: Cambridge University Press, pp. 87-286.

Fichte, Johann Gottlieb (1992): Foundations of Transcendental Philosophy: (Wissenschaftslehre) nova methodo (1796/99). Ithaca, NY: Cornell University Press.

Fichte, Johann Gottlieb (1994): "On the Basis of Our Belief in a Divine Governance of the World". In: Fichte, Introductions to the Wissenschaftslehre and Other Writings (1797-1800). Indianapolis: Hackett, pp. 141-154.

Fichte, Johann Gottlieb (1994a): “Second Introduction to the Wissenschaftslehre". In: Fichte, Introductions to the Wissenschaftslehre and Other Writings (1797-1800). Indianapolis: Hackett, 1994, pp. 36-105.

Fichte, Johann Gottlieb (2001): “Review of Creuzer's Skeptical Reflections on Free Will”. In: Philosophical Forum 32, pp. 289-296.

Fichte, Johann Gottlieb (2005): The Science of Knowing: J. G. Fichte's 1804 Lectures on the Wissenschaftslehre. Albany, NY: State University of New York Press.

Forberg, Friedrich Karl (1912): “Entwickelung des Begriffs der Religion”. In: Die Schriften zu J. G. Fichtes Atheismus-Streit. München: Georg Müller, pp. 37-58.

Frank, Manfred/Kurz, Gerhard (Eds.) (1975): Materialen zu Schellings philosophischen Anfängen. Frankfurt am Main: Suhrkamp.

Franks, Paul (2005): All or Nothing: Systematicity, Transcendental Arguments, and Skepticism in German Idealism. Cambridge, Mass.: Harvard University Press.

Fries, Jakob Friedrich (1989): Knowledge, Belief, and Aesthetic Sense. Cologne: Jürgen Dinter Verlag.

Fries, Jakob Friedrich (1812): Von Deutscher Philosophie Art und Kunst: Ein Votum für Friedrich Heinrich Jacobi gegen F. W. J. Schelling. Heidelberg: Mohr und Zimmer.

Fries, Jakob Friedrich (1828): Neue oder anthropologische Kritik. 2nd. Ed., Vol. 1. Heidelberg: Christian Friedrich Winter.

Gardner, Sebastian (2007): "The Status of the Wissenschaftslehre: Transcendental and Ontological Grounds in Fichte”. In: Internationales Jahrbuch des Deutschen Idealismus Metaphysik im Deutschen Idealismus / International Yearbook of German Idealism Metaphysics in German Idealism 5, pp. 90-125.

Gardner, Sebastian (2011): "Kant's Practical Postulates and the Limits of the Critical System". In: Bulletin of the Hegel Society of Great Britain 63, 187-215. 
di Giovanni, G. (2005): Freedom and Religion in Kant and His Immediate Successors: The Vocation of Humankind, 1774-1800. Cambridge: Cambridge University Press.

Hegel, Georg Wilhelm Friedrich (1975): Encyclopedia Logic. Oxford: Oxford University Press.

Hegel, Georg Wilhelm Friedrich (1977): Faith and Knowledge. Albany, NY: State University of New York Press.

Hegel, Georg Wilhelm Friedrich (1977a): Phenomenology of Spirit. Oxford: Oxford University Press.

Hegel, Georg Wilhelm Friedrich (1977b): The Difference Between Fichte's and Schelling's System of Philosophy. Albany, NY: State University of New York Press.

Hegel, Georg Wilhelm Friedrich (1984): Hegel: The Letters. Bloomington: Indiana University Press.

Hegel, Georg Wilhelm Friedrich (1996): “The Spirit of Christianity and its Fate”. In: Early Theological Writings. Richard Kroner (Ed.). Chicago: University of Chicago Press, pp. $182-301$.

Hegel, Georg Wilhelm Friedrich (2002): “The Tübingen Essay”. In: Miscellaneous Writings of Hegel. Jon Stewart (Ed.). Evanston, Illinois: Northwestern University Press, pp. 44-71.

Henrich, Dieter (1960): Der ontologische Gottesbeweis. Sein problem und seine Geschichte in der Neuzeit. Tübingen: Mohr/Siebeck 1960.

Henrich, Dieter (1997): “Dominant Philosophical-Theological Problems in the Tübingen Stift During the Student Years of Hegel, Hölderlin, and and Schelling”. In: The Course of Remembrance and Other Essays on Hölderlin. Stanford: Stanford University Press, pp. 31-54.

Hölderlin, Friedrich (1954): Sämtliche Werke: Grosse Stuttgarter Ausgabe, Bd. VI, 1te Hälfte, Briefe. Stuttgart: Kohlhammer.

Hölderlin, Friedrich (1957): Hyperion. Die vorletzte Fassung, in Sämtliche Werke: Grosse Stuttgarter Ausgabe. Vol. III. Stuttgart: Kohlhammer, pp. 235-252.

Hölderlin, Friedrich (2009): Essays and Letters. Harmondsworth: Penguin.

Hölderlin, Friedrich (2009a): "The lyric, in appearance idealistic poem ...”. In: and Letters. Harmondsworth: Penguin, pp. 302-306

Hölderlin, Friedrich (2009b): "When the poet is once in command of the spirit ...". In: and Letters. Harmondsworth: Penguin, pp. 277-298.

Jacobi, F. H (1968): “Ueber das Unternehmen des Kriticismus die Vernunft zu Verstande zu bringen". In: Werke. Vol.3. Darmstadt: Wissenschaftliche Buchgesellschaft, pp. 57-195.

Jacobi, F. H (1968a): "Von den göttlichen Dingen und ihrer Offenbarung”. In: Werke. Vol. 3. Darmstadt: Wissenschaftliche Buchgesellschaft, pp. 245-460.

Jacobi, F. H. (1994): "David Hume on Faith, or Idealism and Realism. A Dialogue”. In: The Main Philosophical Writings and the Novel 'Allwill'. George di Giovanni (Ed.). Montreal/Kingston: McGill-Queen's University Press, pp. 253-338.

Jaeschke, Walter (1990): Reason in Religion: The Foundations of Hegel's Philosophy of Religion. Berkeley: University of California Press.

Kant, Immanuel (1992): The Jäsche Logic, in Lectures on Logic. Cambridge: Cambridge University Press.

Kant, Immanuel (1996): Critique of Practical Reason. In: Kant, Practical Philosophy. Cambridge: Cambridge University Press.

Kant, Immanuel (1996a): Groundwork of the Metaphysics of Morals. In: Kant, Practical Philosophy. Cambridge: Cambridge University Press. 
Kant, Immanuel (1996b): “What Does it Mean to Orient Oneself in Thinking?" In: Kant,

Religion and Rational Theology. Allen W. Wood/George di Giovanni (Eds.). Cambridge:

Cambridge University Press, pp. 1-18.

Kant, Immanuel (1998): Critique of Pure Reason. Cambridge: Cambridge University Press.

Kant, Immanuel (1999): Correspondence. Cambridge: Cambridge University Press.

Kant, Immanuel (2000): Critique of the Power of Judgement. Cambridge: Cambridge University Press.

Kant, Immanuel (2005): Notes and Fragments. Cambridge: Cambridge University Press.

Kneller, Jane (2007): Kant and the Power of Imagination. Cambridge: Cambridge University Press.

Neiman, Susan (1994): The Unity of Reason: Rereading Kant. Oxford: Oxford University Press. Novalis (2003): Fichte Studies. Cambridge: Cambridge University Press.

Schelling, Friedrich Wilhelm Joseph von (1927-59): "Ueber Offenbarung und Volksunterricht", in Schellings Werke. Manfred Schröter (Ed.). Vol. I. München: Beck, pp. 474-482.

Schelling, Friedrich Wilhelm Joseph von (1977): Philosophie der Offenbarung 1841/42. Frankfurt am Main: Suhrkamp.

Schelling, Friedrich Wilhelm Joseph von (1978): System of Transcendental Idealism. Charlottesville: University of Virginia.

Schelling, Friedrich Wilhelm Joseph von (1980): "Of the I as Principle of Philosophy, or On the Unconditional in Human Knowledge”. In: The Unconditional in Human Knowledge: Four Early Essays 1794-1796. Fritz Marti(Ed.). Lewisburg: Bucknell University Press, pp. 59-149.

Schelling, Friedrich Wilhelm Joseph von (1980a): “On the Possibility of a Form of All Philosophy”. In: The Unconditional in Human Knowledge: Four Early Essays 1794-1796. Fritz Marti (Ed.). Lewisburg: Bucknell University Press, pp. 38-58.

Schelling, Friedrich Wilhelm Joseph von (1980b): Philosophical Letters on Dogmatism and Criticism. In: The Unconditional in Human Knowledge: Four Early Essays 1794-1796. Lewisburg: Bucknell University Press, pp. 156-218.

Schelling, Friedrich Wilhelm Joseph von (1982): “Antikritik”. In: Friedrich Wilhelm Joseph Schelling, Historisch-Kritische Ausgabe. Reihe I, Vol. III. Annemarie Pieper/Hartmut Buchner/ Wilhelm G. Jacobs (Eds.). Stuttgart-Bad Cannstatt: Fromann-Holzboog, pp. 177-197.

Schelling, Friedrich Wilhelm Joseph von (1984): Bruno, or On the Natural and the Divine Principle of Things. Albany, NY: State University of New York Press.

Schelling, Friedrich Wilhelm Joseph von (1988): Ideas for a Philosophy of Nature as Introduction to the Study of this Science. Cambridge: Cambridge University Press, pp. $43-55$.

Schelling, Friedrich Wilhelm Joseph von (1994): Treatise Explicatory of the Idealism in the Science of Knowledge, in Idealism and the Endgame of Theory: Three Essays. Albany: State University of New York Press, pp. 61-138.

Schelling, Friedrich Wilhelm Joseph von (2000): "On the Relationship of The Philosophy of Nature to Philosophy in General”. In: Between Kant and Hegel: Texts in the Development of German Idealism. George di Giovanni/ H. S. Harris (Eds.). Indianapolis/Cambridge: Hackett.

Schelling, Friedrich Wilhelm Joseph von (2007): Grounding of Positive Philosophy. Albany, NY: State University of New York Press. 
Schmidt, Heinrich (1974): Philosophisches Wörterbuch. Stuttgart: Alfred Kröner.

Storr, Christian (1794): Bemerkungen über Kants philosophische Religionslehre. Tübingen: J. G. Cotta.

Timm, Hermann (1974): Gott und die Freiheit. Studien zur Religionsphilosophie der Goethezeit, Bd. 1. Die Spinozarenaissance. Frankfurt am Main: Klostermann.

Unkown (1995): “Oldest system-programme of German Idealism”. In: European Journal of Philosophy 3, pp. 199-200.

Wallner, Ingrid M. (1985): “A New Look at J. S. Beck's 'Doctrine of the Standpoint”. In: Kant-Studien 75, pp. 294-316. 
Brought to you by | UCL - University College London 